\title{
IL-6 and extracellular matrix remodeling
}

\author{
J. A. Solís Herruzo, P. de la Torre, T. Díaz Sanjuán, I. García Ruiz and T. Muñoz Yagüe \\ Department of Medicine, Gastroenterology. Research Center. Hospital Universitario 12 de Octubre. Madrid, Spain
}

Solís Herruzo JA, de la Torre P, Díaz Sanjuán T, García Ruiz I, Muñoz Yagüe T. IL-6 and extracellular matrix remodeling. Rev Esp Enferm Dig 2005; 97: 575-595.

\section{ABBREVIATIONS}

AP1: activator protein 1; CAT: Chloramphenicol acetyl transferase; ECM: Extracellular matrix; HSCs: Hepatic stellate cells; Jak: Janus tyrosine kinases; JNK: c-Jun N-terminal kinase; MMPs: Matrix metalloproteinases; PP2A: Protein phosphatase 2A; TIMPs: Tissue inhibitor MMPs; IL-6: Interleukin-6.

\section{INTRODUCTION}

Hepatic fibrosis is a characteristic feature of chronic liver diseases. It is the result from the excessive deposition of extracellular matrix (ECM) proteins into the liver in response to a number of liver injuries, including chronic ethanol ingestion, viral hepatitis and iron deposition. Hepatic fibrosis has important physiopathologic consequences on the liver function and structure. First, it may contribute to increase intrahepatic vascular resistances to the portal flow and to originate portal hypertension. Activated hepatic stellate cells may contribute to this effect,

Acknowledgment: This study was supported in part by a Grant for Medical Research from the "Fundación Mutua Madrileña" (Spain, 2004).

Recibido: 04-01-05.

Aceptado: 08-01-05.

Correspondencia: José A. Solís Herruzo. Servicio de Patología Digestiva. Hospital 12 de Octubre. Avda. de Córdoba, s/n. 28041 Madrid. Fax: 91 3908280. e-mail: jsolis.hdoc@salud.madrid.org since these cells exhibit contractile capacity and can modulate blood flow at the sinusoidal level (1). Second, perisinusoidal fibrosis represents a barrier to the exchange of nutrients and metabolites between sinusoidal blood and hepatocytes. Furthermore, deposition of ECM in the space of Disse induces the loss of fenestrae of the sinusoidal endothelial cells (2). Third, ECM is a physiological reservoir for cytokines and growth factors in the close cell surrounding. The binding of these factors to ECM component modulates their biological activity and protects them from proteolysis (3).

EMC of the liver is composed of three distinct types of proteins including collagen, noncollagenous glycoproteins, and proteoglycans (Fig. 1). Collagen type I, III and $V$ are heterotrimer molecules that form a triple helical structure with a tendency to form supramolecular aggregates $(4,5)$. Type $V$, a pericellular collagen in the normal liver, is also present in increased amount in septa and portal tracts. Collagen $I V$ is the major collagen of basement membrane. It is an unusual collagen type in that molecules cross-link at their terminal domains to form a network. This sheet of collagen is physically intermeshed or directly bound to other components of the basement membrane like laminins, nidogen, or perlecan.

In the hepatic fibrosis and cirrhosis, all types of collagens are increased. When hepatic fibrosis is mild, collagen type I and III are equally increased. However, when hepatic fibrosis is severe, the predominant collagen in the connective tissue bands is type I, and the ratio of collagen I to collagen III increased to $4: 1$ (5). In these conditions, collagen IV is deposited mainly in the space of Disse, transforming sinusoids into capillaries. Although collagen I becomes the predominant ECM constituent in fibrosis and cirrhosis, many other proteins also are part of the fibrous complex. Thus, glycoproteins (fibronectin, laminins, tenascin, undulin, thrombospondin, SPARC) and proteoaminoglycans (perlecan, biglycan, decorin, aggrecan) also are increased in scars and septa. 


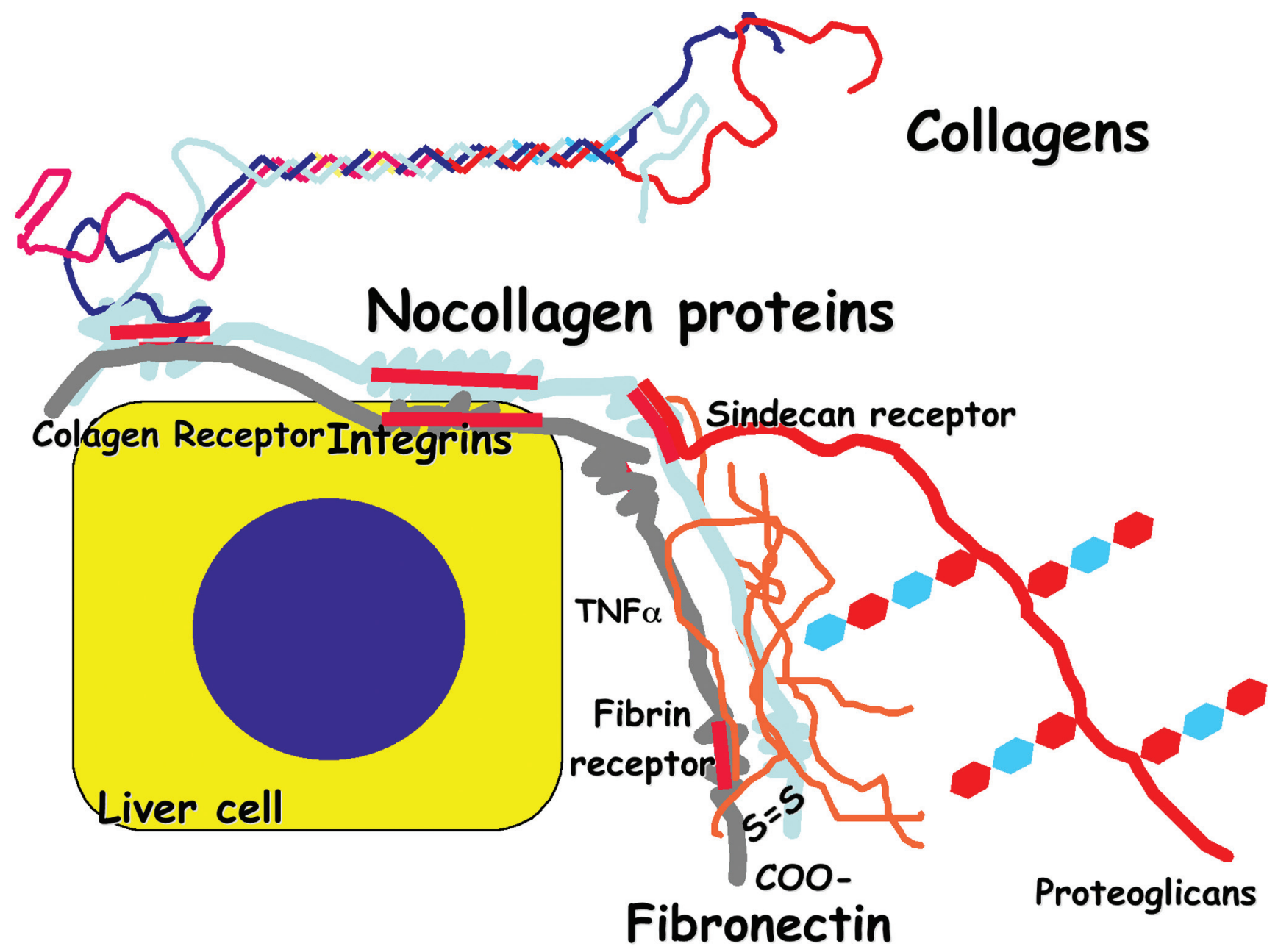

Fig. 1.- Composition of the extracellurar matrix.

Matriz extracelular.

Although it is likely that each cell population in the liver plays a role in the production of ECM components, hepatic stellate cells (HSCs) appear to be the major fibrogenic cell type (6). HSCs are resident nonparenchymal cells located in the subendothelial space between hepatocytes and sinusoidal endothelial cells. In normal liver, HSCs are relatively quiescent with respect to ECM synthesis $(7,8)$. However, during liver injury, they undergo a complex process that transforms quiescent HSC to one activated cell that is proliferative, fibrogenic, and contractile $(9,10)$. HSC activation is associated with changes in the metabolism (increased DNA synthesis, cellular proliferation), the pattern of gene expression [collagen I, III, IV, laminin, fibronectin, MMPs (Matrix Metalloproteinases), TIMPs (Tissue Inhibitor of MMPs)], and the capacity to synthesize cytokines, growth factors and their receptors.
Extensive fibrosis in experimental liver injury may resolve upon withdrawal of the injurious agent. Thus, fibrosis or cirrhosis induced by biliary obstruction or carbon tetrachloride intoxication in rat is reversible over a period of one to three months (11). Likewise, reversible fibrosis has been shown in mouse and rabbit models of hepatosplenic schistosomiasis (12). Current evidence indicates that regression of liver fibrosis and advanced micronodular cirrhosis is a real phenomenon if the original cause of the liver injury is effectively removed (13-17). However, this process may be incomplete over a prolonged period and results in the development of maconodular cirrhosis. Remodeling of this residual lesion is limited by matrix cross-linking (18). Transglutaminase-mediated cross-linking of collagen provides matrix proteins with resistance to MMP-mediated degradadation (19). Thus, these linking may limit matrix degradation even in the presence of active MMPs. 
Degradation of the ECM in the hepatic fibrosis is a complex process involving MMPs, specific TIMPs, and enzymes that activate latent MMPs (20). In an experimental model of liver fibrosis, transient MMPs overexpression in the liver effectively attenuates established fibrosis (21).

MMPs constitute a large family of structurally related zinc-dependent endopeptidases capable of degrading a wide variety of ECM components (22-24), and, therefore, they may play a key role in the resolution of liver fibrosis upon withdrawal of the injurious agent. MMP-1 and MMP-13 cleave interstitial collagens (types I, II, III and X). MMP-2 (gelatinase A) and MMP-9 (gelatinase B) degrade denatured interstitial collagen (gelatins), type $\mathrm{V}$ and IV collagens, and noncollagen proteins (fibronectin, laminin, elastin). MMP-3 (stromelysin-1), MMP-10 (stromelysin-2) and MMP-7 (matrilysin) degrade a broad range of substratres, including proteoglycans, and collagen and noncollagen proteins. Membrane-type MMPs (MMP-14 to MMP-25) are anchored to the surface of cells through their carboxyl-terminal transmembrane domain. These membrane-type MMPs degrade collagen and noncolagenous proteins, proteoglycans and play an important role in the activation of MMP-2 and MMP-13. In rats and mice, there is only one interstitial MMP, the MMP-13, which shares $86 \%$ homology with human MMP-13. MMP-13 is capable of degrading type I, II, III, IV, X, and XIV collagens, tenascin, fibronectina and the aggrecan protein (25).

MMPs are secreted as inactive proenzymes; therefore they need to be subsequently activated by several mechanisms including enzymatic cleavage (serine protease plasmin, stromelysin-1, membrane-type MMPs) $(20,26)$. Activated MMPs produce a limited number of cleavages within the triple helix of the three $\alpha$-chain of interstitial collagen molecules, e.g. in type I collagen, cleavage occurs between Gly ${ }^{775}$ and Ile ${ }^{776}$ in the $\alpha_{1}$ chain and the corresponding Gly/Leu in the $\alpha_{2}$ chain, to yield typical threefourths length amino-terminal and one-fourth length carboxyl-terminal fragments. This initial single site cleavage of interstitial collagens results in their partial unfolding, which then renders them susceptible to degradation to small fragments by gelatinases. The activity of MMPs is regulated by a complex mechanism at the level of gene expression, proenzyme activation, or binding of proenzyme or active enzyme to TIMPs.

TIMPs are low molecular weight glycoproteins capable of irreversibly binding to proenzyme or active form of MMPs with a 1:1 stoichiometry and inactivating a wide variety of MMPs degrading enzymes. Because of the one-to-one interactions, small changes in levels of TIMPs can lead to significant changes in the biological activity of MMPs. Excess production of TIMPs relative to MMPs could contribute to the progression of liver fibrosis, while the enhancement of matrix breakdown may be achieved by either reducing the synthesis of TIMPs or increasing the expression of MMPs. All members of this family are able to inhibit all of the MMPs. However, some TIMPs have specific relationship with individual MMPs $(27,28)$. TIMPs are multifunctional molecules that not only inhibit MMPs but also stimulate proliferation of various cell types and can protect cells from apoptosis $(29,30)$.

The severity of hepatic fibrosis is the result of the degree of collagen synthesis and the fate of the collagen deposited into the ECM of the liver, which, in turn, depend on the balance between the production and the activation of MMPs and the levels of TIMPs. In chronic liver disease in human and in animal models of liver fibrosis, expression of MMP-1/MMP-13 does not change significantly, as hepatic fibrosis develops and progresses, but there is a striking increase in expression of TIMP-1 and TIMP-2 (31). In homogenates prepared from fibrotic livers, the level of TIMP-1 protein increases approximately five-fold in comparison with normal liver. Regression of hepatic fibrosis is characterized by degradation of ECM and restoration of normal liver histology. Following cessation of injury, there is a five-fold increase in collagenase activity in the liver, which is associated with a progressive decrease in the level of expression of TIMP-1 and TIMP-2, but no change in the level of expression of MMP-13. Studies in cultured HSCs have explored the molecular basis of the up-regulation of TIMP-1 during hepatic fibrogenesis. These studies have identified a key region in the TIMP-1 promoter that is critical to gene expression (32). However, up to now, it has not been identified the proteins interacting with this region. Many cell types, particularly HSCs, Kupffer cells and inflammatory cells, produce several MMPs in culture $(20,26)$.

Very few studies have examined the effect of cytokines on ECM degradation in HSCs. However, it is well known that MMP production can be up-regulated by several hormones (PTH, cortisol), growth factors (platelet derived growth factor, basic fibroblast growth factor), cytokines (TNF $\alpha$, IL-1 $\alpha$, IL-6, IL-10, IFN $\gamma$, oncostatin $\mathrm{M}$, macrophage migration inhibitory factor) and tumor promoters (phorbol esters). On the other hand, MMP-13 is down-regulated by transforming growth factor (TGF $\beta$ ), insulin-like growth factor (ILGF) $(20,26,33$ 40). Likewise, several cytokines (TNF $\alpha$, IL1 $\beta$, IL-6, oncostatin $\mathrm{M}, \mathrm{IFN} \alpha)$ and growth factors (TGF $\beta$ ) up-regulate (41-43) or inhibit (44-47) TIMPs expression by cultured HSCs.

Interleukin-6 (IL-6) is a multifunctional glycoprotein produced by activated monocytes, macrophages, endothelial cells, and hepatic stellate cells that mediates a wide variety of functions in different cells, including fibroblasts, hepatocytes, and hepatic stellate cells (48). IL-6 promotes cell proliferation and differentiation and regulates specific gene expression (49), particularly the expression of the acute phase proteins in liver cells $(48,50)$. Acute and chronic liver diseases, particularly alcoholic liver diseases, are similar to the acute phase response in some respects. Thus, patients with alcoholic 
hepatitis show fever, muscle wasting, neutrophilia, and increased production of C-reactive protein, $\alpha_{1}$-antitrypsin and amyloid A (50,51). High levels of IL-6 have been detected in the sera of patients with alcoholic liver cirrhosis (52-54) and some authors have shown a correlation between circulating concentrations of IL- 6 and serum concentrations of C-reactive protein $(55,56)$, an IL-6-induced protein. Thus, IL- 6 seems to be one of the most important factors regulating inflammatory response in the liver.

We have shown that IL-6 increases MMP-13 protein levels and the steady-state levels of MMP-13 mRNA in a dose- and time-dependent fashion (Fig. 2) and that this effect is produced acting within the gene promoter (57). This effect is evident after 6 hours of treatment but it is particularly significant after 24 hours. This prolonged incubation time required by IL- 6 to activate MMP-13 gene expression suggests that it may be required the synthesis

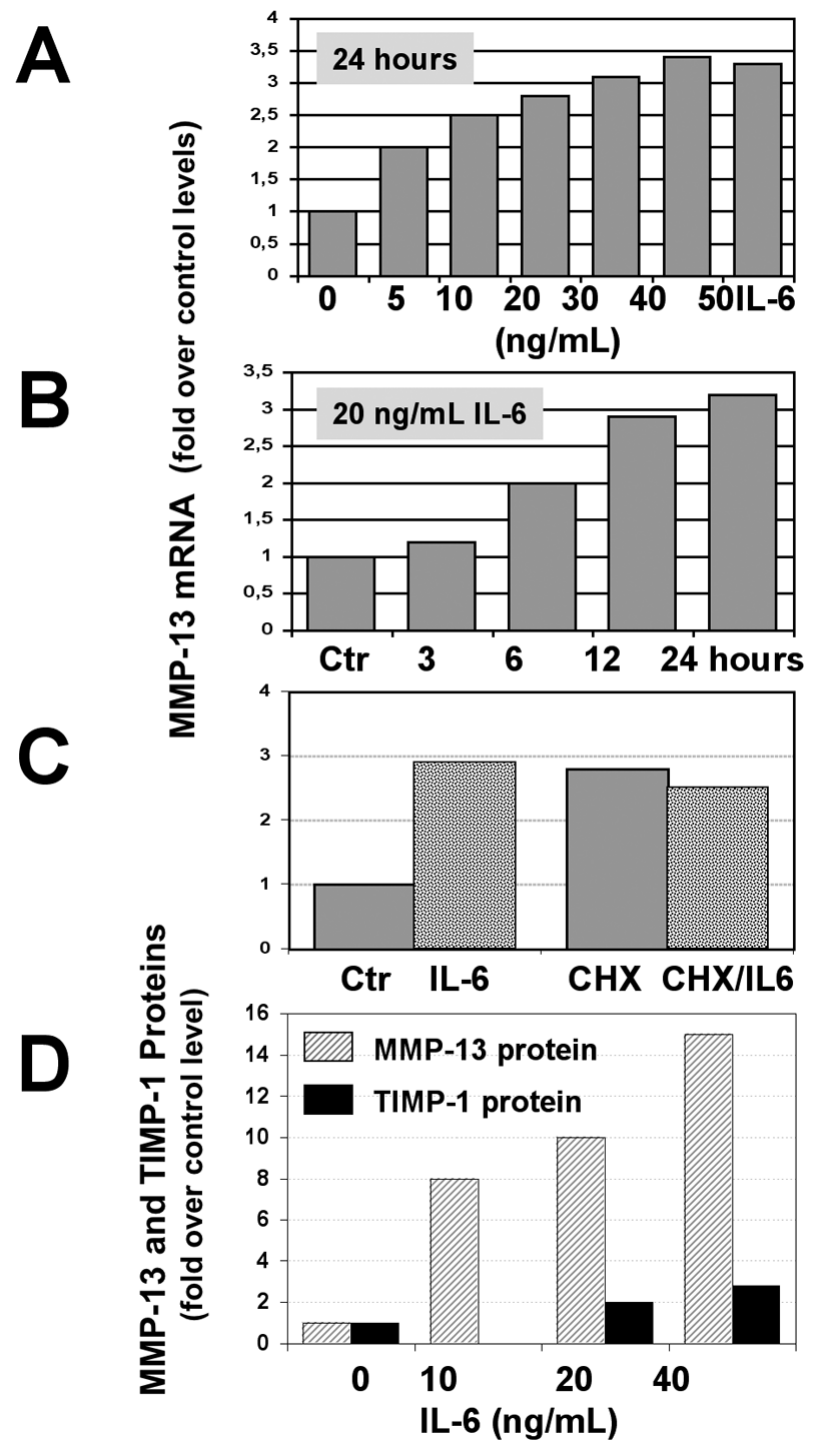

of a new protein. The IL-6-induced increase in MMP-13 mRNA levels can be blocked by inhibiting the protein synthesis with cycloheximide (Fig. 2C), which supports this requirement.

This enhanced MMP-13 gene expression is associated with a marked increase in the immunoreactive MMP-13 protein (Fig. 2D). These results agree with those reported by Franchimont et al. (58) and Kusano et al. (59), who also demonstrated that IL-6, in the presence of its soluble receptor, increased MMP-13 mRNA levels, immunoreactive MMP-13 and its biological activity. It is likely that IL-6 has an effect on the extracellular metabolism of MMP-13, since the effect of this cytokine on MMP-13 secreted into the culture medium is much higher than that induced on the steady-state level of MMP-13 mRNA. Although some authors have shown that IL-6 significantly enhanced TIMP-1 production and TIMP-1 mRNA expression in human fibroblasts and other cell lines (60-64), in our experience, IL-6 also increases immunoreactive TIMP-1, but to a lesser extent (Fig. 2D). In fact, TIMP-1 and MMP-13 promoters contain common regulatory elements, i.e. an AP1 binding site (TRE) and PEA-3 (65). Therefore, factors that up-regulate MMP-13 gene expression may also stimulate TIMP-1 expression.

Fig. 2.- (A) Dose-response effect of IL-6 on MMP-13 mRNA. Confluent Rat-1 fibroblasts were incubated for 24 hours in the absence or presence of increasing concentration of IL-6. (B) Time-response effect of $20 \mathrm{ng} / \mathrm{mL} \mathrm{IL}-6$ on MMP-13 mRNA. (C) MMP-13 mRNA in cells incubated for 24 hours in control medium /Ctr) or in medium containing 20 $\mathrm{ng} / \mathrm{mL} \mathrm{IL}-6$ in the presence or absence of $0.1 \mathrm{mM}$ cycloheximide (CHX). MMP-13 mRNA was measured by Northern blot analysis. The autoradiograms were quantitated by scanning laser densitometry. Bars represent the level of MMP-13 mRNA in each sample after normalization to the level of 18S RNA. Values are given as fold over the value in control cells. (D) Medium harvested from cells untreated and treated with 10, 20 , or $40 \mathrm{ng} / \mathrm{ml}$ was analyzed by Western blot with antibody against human MMP-13. Likewise, samples of medium harvested from cells untreated or treated with 20 or $40 \mathrm{ng} / \mathrm{ml} \mathrm{IL-6}$ were concentrated, and $30 \mu \mathrm{g}$ protein from each sample were analyzed by Western blot with specific antibody against rat TIMP-1. There is a dose-dependent increase in the amount of immunoreactive MMP-13 and TIMP-1.

(A) Efecto de la dosis de IL-6 sobre el ARNm de la MMP-13. Fibroblastos Rat-1 fueron incubados durante 24 horas en ausencia o presencia de concentraciones crecientes de IL-6. (B) Efecto del tiempo de exposición a $20 \mathrm{ng} / \mathrm{mL}$ de IL-6 sobre el ARNm de la MMP-13. (C) ARNm de la MMP-13 en células incubadas durante 24 horas en medio control o en medio que contenía $20 \mathrm{ng} / \mathrm{mL} / \mathrm{L}-6$ en presencia o ausencia de 0,1 mM de cicloheximida (CHX). El ARNAm de la MMP-13 fue determinado por Northern blot. Las autoradiografías fueron cuantificadas mediante densitometría de láser. Las barras representan los niveles de ARNm de la MMP-13 en cada muestra tras su normalización con los niveles de ARN 18S. Los valores son expresados como veces sobre el valor en las células controles. (D) Se analizaron las proteínas del medio de cultivo de células tratadas y no tratadas con 10, 20 o $40 \mathrm{ng} / \mathrm{mL}$ mediante Western blot utilizando para ello anticuerpos frente a la MMP-13 humana. Igualmente, se concentraron muestras de medio de cultivo de células tratadas con $20040 \mathrm{ng} / \mathrm{mL}$ de IL-6. Treinta microgramos de estas proteínas fueron analizadas mediante Western blot empleando anticuerpos frente al TIMP-1 de rata. Se produce un aumento dependiente de la dosis en la cantidad de MMP-13 y de TIMP-1 inmunorreactivas. 
Rat MMP-13 promoter displays a general organization similar to that of other members of the MMP family $(66,67)$, particularly to human (68) and rabbit MMP-1 genes (69). All share a common 10-exon organization $(67,68,70)$ and contain a typical TATA box in addition to TRE and polyomavirus enhancer activator 3 (PEA-3) consensus site in their promoter region (67,71-74), suggesting a common regulatory mechanism of gene transcription. Rat MMP-13 gene also contains several consensus transcription factor recognition sequences such as C/EBP, Cbfa1, p53, AP-2, and AP1 (75) (Fig. 3). In cells transfected with plasmids whose activity is driven by portions of different length of the MMP-13 gene promot- er, we found that sequences upstream of the base pair -79 are dispensable in IL-6-medited stimulation of MMP-13 gene expression. These experiments also show that integrity of the TRE site appears to be essential for the IL-6 induced response (Fig. 4). The TRE site has been implicated in the expression of many of the MMP genes (76,77), including MMP-13 (77). In cells transfected with a luciferase construct containing two copies of the TRE upstream of a minimal promoter, we were able to confirm this stimulatory effect of IL-6 on the TRE site (Fig. 5). Very little information exists about the effect of IL-6 on the activation of genes with a TRE. However, while Daffada et al. (78) found that IL-6 had no effect on the ex-

Fig. 3.- Schematic representation of the rat MMP-13 gene promoter. (+) Sign indicates the transcription start site.

Representación esquemática del promotor genético de la MMP-13 de rata. El signo (+) indica el lugar de inicio de la transcripción genética.

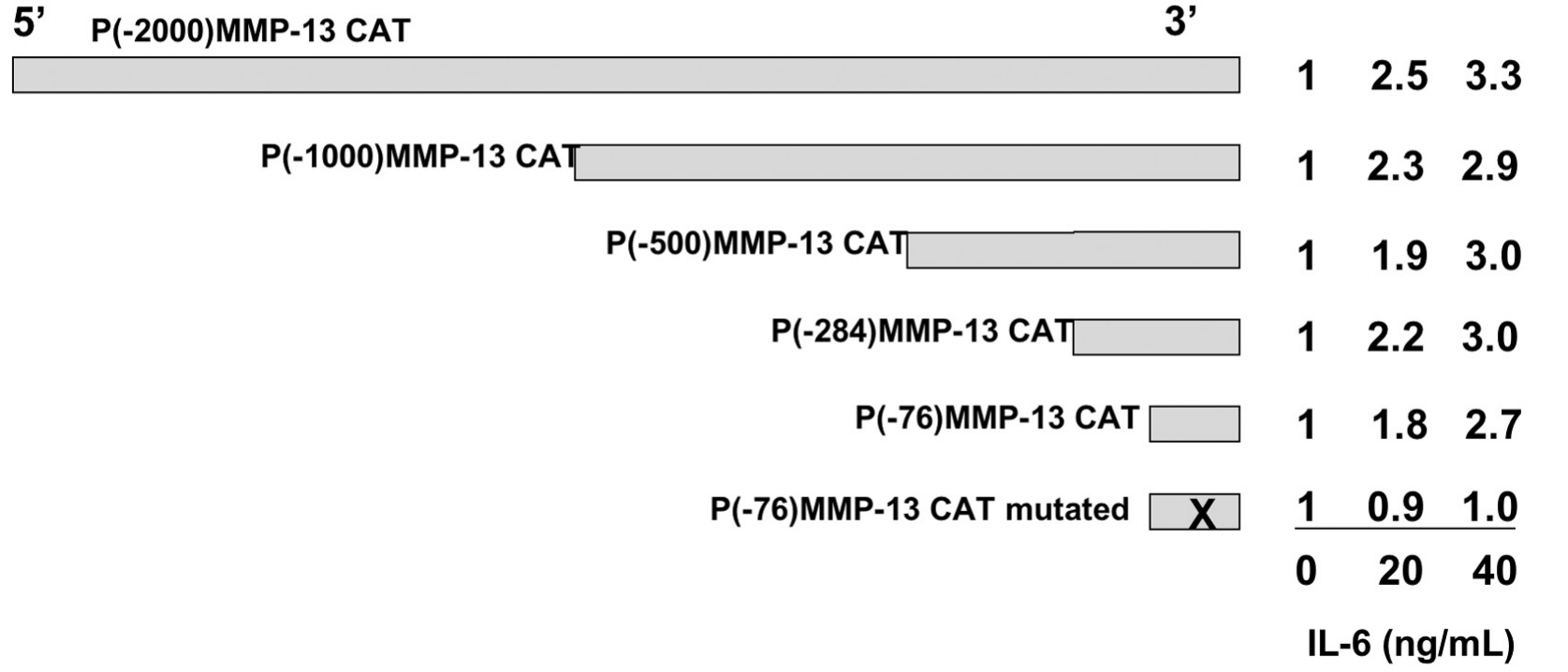

Fig. 4.- Rat 1 fibroblasts were transiently transfected with a series of MMP-13-CAT constructs obtained by removing progressively more $5^{\prime}$-flanking sequences of the MMP-13 promoter and exposed to 0,20 , or $40 \mathrm{ng} / \mathrm{mL}$ IL-6 for 24 hours. Cell lysated were assayed for chloramphenicol acetyl transferase (CAT) activity. CAT activity is expressed as fold over control activity. Deletion of promoter sequences upstream of base pair -76 relative to the transcription start site does not abrogate the effect of IL-6 on MMP-13 gene expression. This effect disappears in cells transfected with a construct in which the AP1 binding site have been mutated (X).

Fibroblastos Rat 1 fueron transfectados con una serie de plásmidos MMP-13-CAT obtenidos eliminando progresivamente secuencias de mayor tamaño del extremo 5' del promotor MMP-13. Estas células fueron expuestas a 0, 20 ó 40 ng/mL de IL-6 durante 24 horas. La actividad CAT fue determinada en los lisados de esas células. La actividad cloranfenicol acetil transferasa (CAT) la expresamos en forma de veces la actividad existente en las células controles. La eliminación de las secuencias proximales al par de bases -76 en relación con el inicio de la transcripción no elimina el efecto de la IL-6 sobre la expresión del gen de la MMP-13. Este efecto desaparece cuando la secuencia consenso AP1 es mutada (X). 


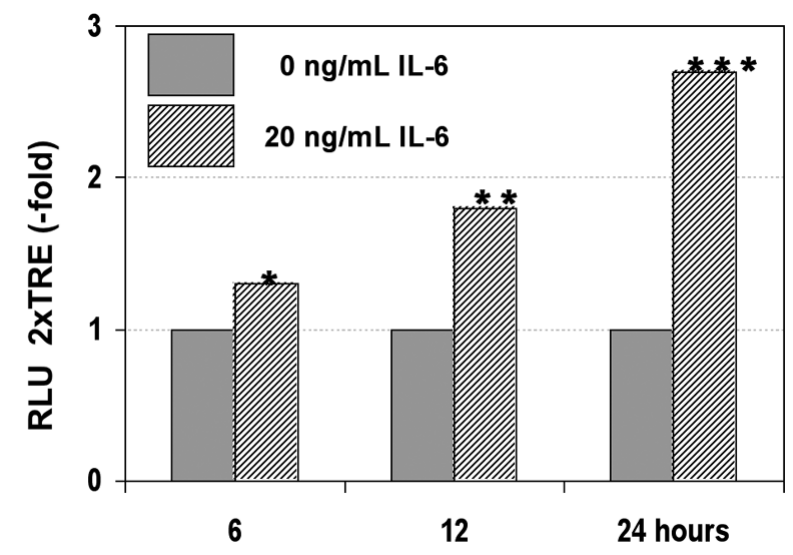

Fig. 5.- Cells were transfected with the p2xTRE-Luc construct and cultured in the absence or presence of $20 \mathrm{ng} / \mathrm{ml} \mathrm{IL-6}$. Luciferase activity was measured after 6,12 or 24 hours of treatment with IL- 6 . Values are given as fold over the activity in control cells. ${ }^{*}: p<0.05 ;{ }^{* *}: p<$ $0.01 ; * * *: p<0.001$ as compared with control cells.

Las células fueron transfectadas con el plásmido p2xTRE-Luc y cultivadas en ausencia o presencia de $20 \mathrm{ng} / \mathrm{mL}$ de IL-6. Se midió la actividad luciferasa tras 6, 12 o 24 horas de tratamiento con IL-6. Los valores son expresados en forma de veces por encima de la actividad en las células controles. *: $p<0,05 ; * *: p<0,01 ; * * *: p<0,001$ comparados con las células controles.

pression of pTRE-CAT in transient transfected cells, suggesting that AP1 is not induced by IL-6 treatment, Melamed et al. (79) showed that IL-6 induced the formation of a TRE-binding complex, which was abrogated by anti-Jun specific antibodies.

Upregulation of gene expression is usually induced by the binding of transcrition factors to specific cis-acting elements in gene promoters. Our study suggested that IL-6 upregulates MMP-13 gene expression via transcription factor AP1 and through the cis-acting element TRE. Thus, gel DNA retardation experiments show that IL-6 promotes a dose- and time-dependent binding of nuclear proteins to TRE site (Fig. 6). Nuclear protein-DNA complexes induced by the IL- 6 treatment contain phosphorylated c-Jun as shown by the incubation of nuclear extract with a phosphorylated c-Jun-specific antibody prior to the gel retardation assay, which lead to the formation of two supershifted complexes. These results support the role played by TRE and AP1 in mediating the effect of IL-6 on rat MMP-13 gene expression.

The AP1 transcription factor is organized into Jun-Jun, Jun-Fos, or Jun-ATF dimmers, and the presence of Jun family members in these dimmers enables AP1 to bind cis-acting elements of gene promoters. These proteins form a variety of homo- and heterodimers that bind to a common DNA recognition site, the TRE $(58,80,81)$. As figures 7 shows, culture of fibroblasts with IL-6 induces c-Jun, JunB and c-Fos mRNA (Fig. 7A), $c$-jun and $c$-fos promoters (Figs. 7B and 7C) and c-Jun and c-Fos proteins (Figs. 8A and 8B). Other authors have also shown

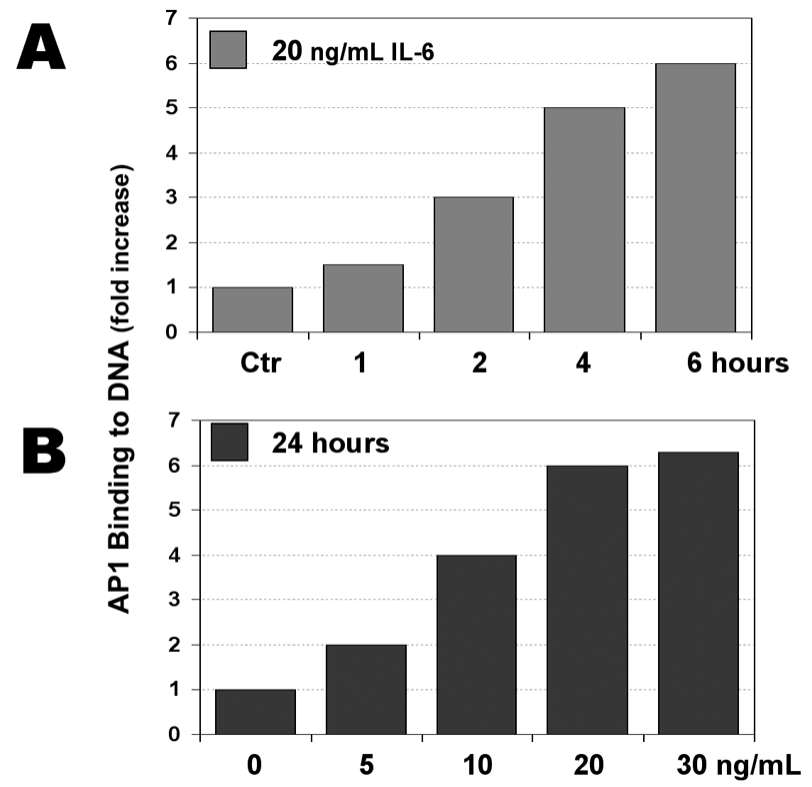

Fig. 6.- (A) DNA binding was analyzed by gel retardation assay. A double stranded radiolabeled AP1 oligonucleotide was incubated with nuclear proteins extracted from control cells or cells treated with 20 $\mathrm{ng} / \mathrm{mL}$ IL- 6 for 1 to 6 hours. (B) Nuclear extracts from cells treated for 24 hours with increasing concentrations of IL- 6 were incubated with radiolabeled AP1 probe. Bars represent the intensity of the AP1-DNA complexes in each experimental condition.

(A) La fijación al ADN a las proteínas nucleares fue analizado mediante la prueba del retardo del ADN en gel. Un oligonucleótido de doble cadena marcado con las secuencias consenso de AP1 fue incubado con un extracto de proteínas nucleares obtenidas de células controles o células tratadas con $20 \mathrm{ng} / \mathrm{mL}$ de IL-6 durante 1 a 6 houras. (B) Extractos nucleares de células tratadas durante 24 horas con concentraciones crecientes de IL-6 fueron incubados con una sonda marcada de AP1. Las barras representan la intensidad de los complejos AP1-ADN en cada condición experimental.

that IL-6 stimulated junB gene expression in a variety of cells (82-86) and Cressman et al. (87) have shown that the expression of junB is markedly reduced in the liver of IL-6-deficient mice.

Transcriptional activity of AP1 depends not only on the quantity of AP1 components and their ability to bind DNA but also on the degree of phosphorylation of these proteins $(80,88)$. Phosphorylation of c-Jun in its activation domain at serine 63 and 73 prolongs its half-life and potentiates the ability of c-Jun to activate transcription as either a homodimer or as a heterodimer with c-Fos (80). Western blot using a specific monoclonal antibody for serine 63 phosphorylated c-Jun demonstrates that IL-6 induces an increase in this form of c-Jun, which is particularly marked after 12 hours of treatment (Fig. 8C). Lütticken et al. (84) also showed that IL-6 triggers a delayed phosphorylation of STAT3 at serine residues. A va- 

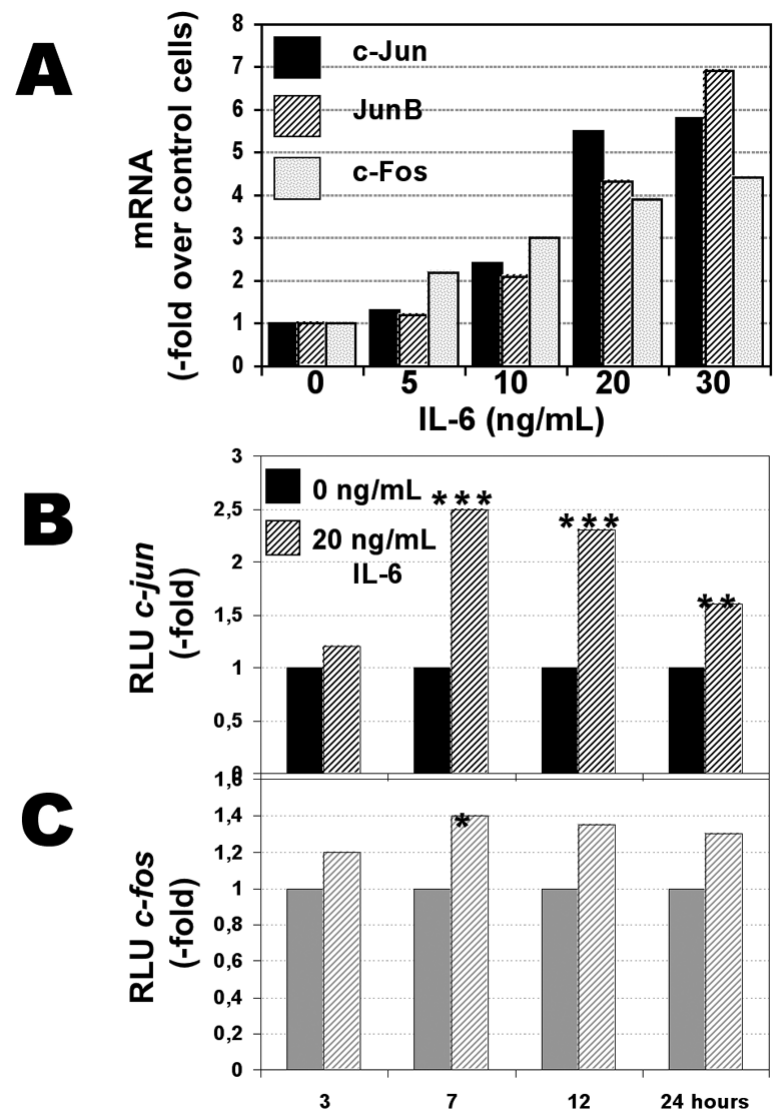

Fig. 7.- (A) Fibroblasts were cultured with $0-30 \mathrm{ng} / \mathrm{mL} \mathrm{IL}-6$ for 24 hours and total RNA was isolated and analyzed by Northern blotting. The blot was hybridazed with ${ }^{32}$ P-labeled probes specific for c-Jun, JunB and c-Fos. Autoradiograms were quantitated by scanning laser densitometry. Bars represent mRNA levels expressed as fold over levels in control cells. ( $B$ and $C$ ) Fibroblasts were transfected with the reporter plasmids pJun-Luc or pFos-Luc. Transfected cells were incubated with 0 or $20 \mathrm{ng} / \mathrm{mL}$ IL- 6 for 3 to 24 hours. After the indicated time, luciferase activity was measured in cell homogenates. Fold represents luciferase activity in the presence of IL- 6 divided by that obtained in the absence of IL-6. RLU are arbitrary luminescence units. $*: p<0.05 ;{ }^{* *}: p<0.01$; $* * *: p<0.001$.

(A) Los fibroblastos fueron cultivados con 0 a $30 \mathrm{ng} / \mathrm{mL}$ de IL-6 durante 24 horas. Se aisló y analizó el ARN total mediante Northern blot. Los blots fueron hibridados con sondas específicas para c-Jun, JunB y c-Fos marcadas con ${ }^{32} P$. Las autorradiografías fueron cuantificadas mediante densitometría láser. Las barras representan los niveles de ARNm expresados en forma de veces por encima del nivel en las células control. (B y C) Los fibroblastos fueron transfectados con el plásmido pJun-Luciferasa (B) o con el pFos-Luciferasa (C). Una vez transfectadas, las células fueron incubadas durante 3 a 24 horas con 0 a $20 \mathrm{ng} / \mathrm{mL}$ de $\mathrm{IL}-6$. Tras el tiempo indicado, la actividad luciferasa fue determinada en los homogenados celulares. Las barras representan la actividad luciferasa en las células tratadas con IL-6 dividida por la actividad en ausencia de IL-6. RLU son unidades arbitrarias de luminiscencia. *: $p<0,05$; **: $p$ $<0,01 ; * * *: p<0,001$.

riety of protein kinases, including JNK (c-Jun N-terminal kinase), pp42, pp54, pp44-, and p38-mitogen-activated protein kinases (89), p34cdc2, protein kinase $\mathrm{C}$, casein kinase II, efficiently phosphorylates c-Jun (90). JNK,

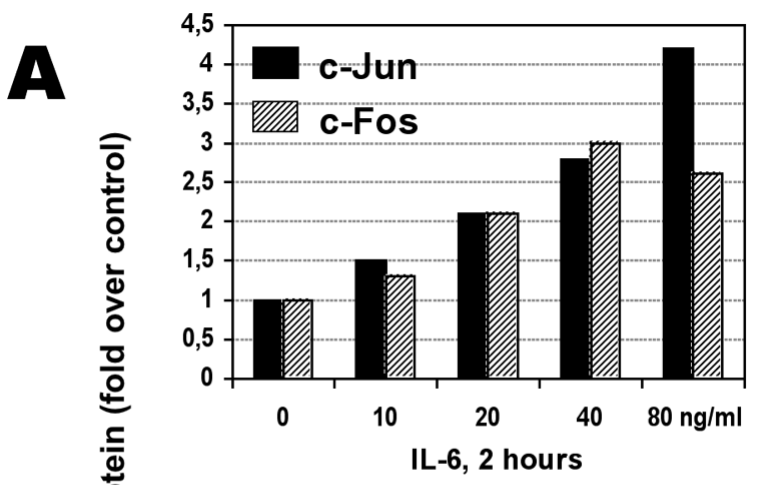

$\mathbf{B}$
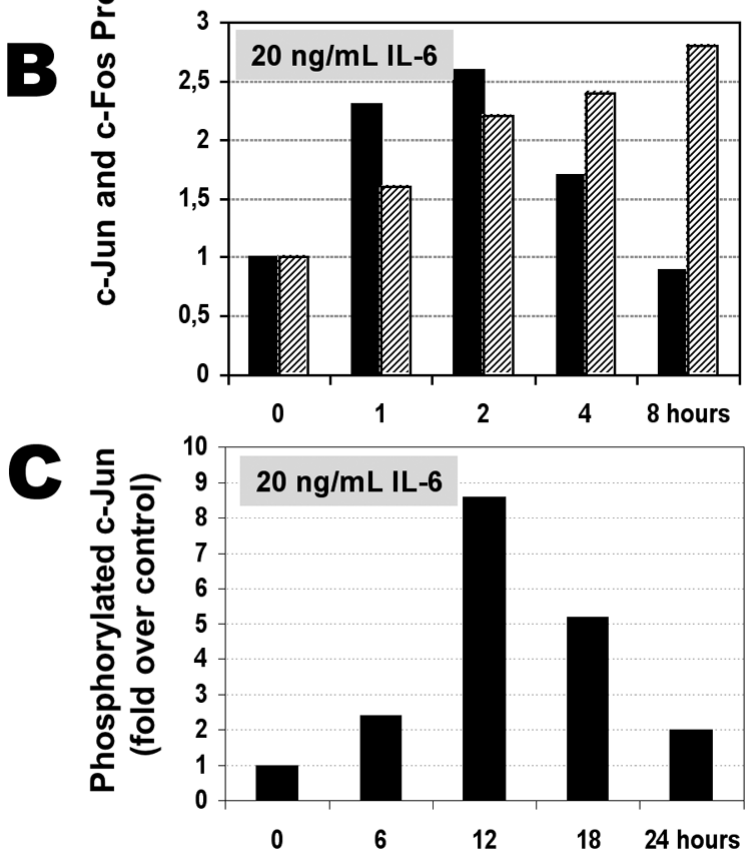

Fig. 8.- Whole cell protein extracts from cells incubated in the absence or presence of increasing concentrations of IL-6 (A) for 1 to 8 hours (B) were separated by SDS-polyacrylamide gel electrophoresis and transferred to membrane for immunoblot analysis. Immunoblots were probed with either specific anti-cJun or anti-c-Fos antibodies and detected by enhanced chemiluminescence. In $C$, immunoblots were probed with specific anti-phosphoserine-63 c-Jun antibody. Bars represent fold protein content in IL- 6 treated cells divided by the protein content in untreated cells.

Extractos de proteínas de células incubadas en presencia o ausencia de concentraciones crecientes de IL-6 (A) durante 1 a 8 horas (B) fueron separadas por electroforesis en un gel de poliacrilamida-SDS y trasferidas a una membrana para análisis por inmunoblot. Los inmunoblots fueron expuestos a anticuerpos específicos frente a anti-c-Jun o anti-cFos y las proteínas fueron detectados por quimioluminiscencia. En C, los inmunoblots fueron revelados con anticuerpos específicos anti-cJun fosforilado en serina-63. Las barras representan el contenido de esas proteínas en las células tratadas con IL-6 dividido por su contenido en las células control.

also known as stress-activated protein kinase (SAPK), is the most efficient member of the mitogen-activated protein kinase (MAPK) family involved in c-Jun phosphorylation on serines 63 and 73 of c-Jun and in potentiating its 
transactivation function $(91,92)$. Moreover, JNK is a critical MAPK pathway for IL-1 induced collagenase gene expression in a variety of cell types (93). However, our study indicates that IL-6 does not induce the phosphorylation of c-Jun by stimulating JNK activity. As figure 9A shows incubation of cells with 10 and $20 \mathrm{ng} / \mathrm{ml} \mathrm{IL-6}$ for 15 minutes, but not for 5 minutes, decreased JNK activity to 84 and $68 \%$, respectively, of that of control cells.
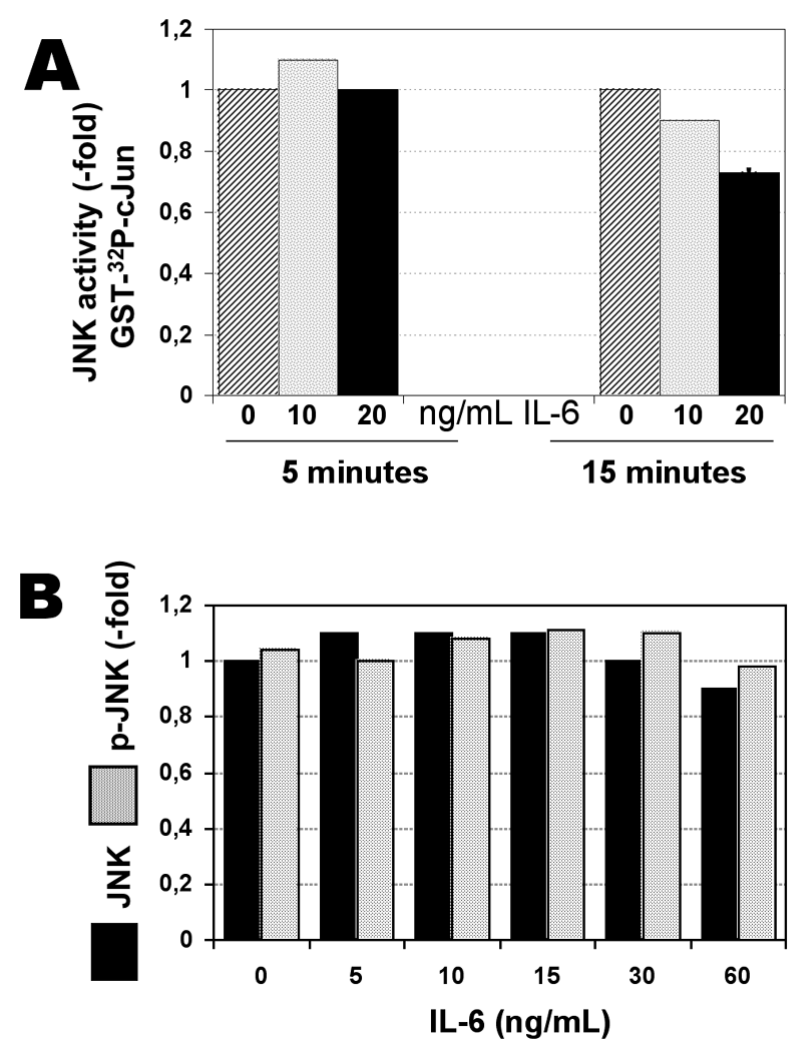

Fig. 9.- (A) IL-6 decreases JNK activity in Rat-1 fibroblasts. Recombinant GST-c-Jun was incubated with $25 \mu \mathrm{g}$ of whole cell protein extracts from cells treated without or with 10 or $20 \mathrm{ng} / \mathrm{mL}$ for 5 and 15 minutes. JNK-mediated phosphorylation of GST-C-Jun is assessed by the incorporation of [ $\left[\gamma^{32}\right.$ P]ATP. * $: p<0.01$. (B) Effects of IL-6 on JNK phosphorylation. Twenty-five micrograms of protein extracts from cells incubated in the presence of $20 \mathrm{ng} / \mathrm{mL} \mathrm{IL-6}$ for 0 to 60 minutes were separated by $8 \%$ SDS-polyacrylamide gel electrophoresis and transferred to membrane for immunoblot analysis. Immunoblot was then probed with specific anti-JNK as control ( $\square$ ) for the subsequent blotting with the anti-phosphorylated JNK antibody ( $\square$ ).

(A) La IL-6 desciende la actividad JNK en fibroblastos Rat-1. GST-C-Jun recombinante fue incubado con $25 \mu \mathrm{g}$ de extractos de proteínas de células tratadas con o sin 10 ó $20 \mathrm{ng} / \mathrm{mL}$ durante 5 a 15 minutos. La fosforilación de GST-c-Jun mediada por la JNK se valora por la incorporación de [ $\gamma^{32}$ PJATP. *: $p<0,01$. (B) Efectos de la IL-6 sobre la fosforilación de JNK. Veinticinco microgramos de extractos de proteínas de células incubadas en presencia de $20 \mathrm{ng} / \mathrm{mL}$ durante 0 a $60 \mathrm{mi}$ nutos fueron separados por electroforesis en gel de 8\% SDS-poliacrilamida y transferidas a una membrana para análisis por inmunoblot. Los inmunoblots obtenidos fueron revelados con anti-JNK especificos como control (ם) para posteriormente ser revelados con anticuerpos anti-JNK fosforilado (口).
Moreover, Western blots using specific polyclonal antibodies against JNK reveal one single band located at $46 \mathrm{kDa}$, the density of which does not change after incubation with IL-6. Likewise, this treatment do not modify phosphorylated JNK, as reveal Western blots using specific monoclonal IgG antibody raised against phosphorylated JNK (Fig. 9B). As dual phosphorylation of serine/threonine amino residues by the MAP kinase kinase (MKK4 and MKK7) is necessary for JNK activation (94), these results support the conclusion that this kinase is not involved in the IL-6-induced increase in phosphorylated c-Jun and MMP-13 gene expression. These results concurs with those reported by a number of authors showing that IL-6 has no detectable effects on JNK $(95,96)$ or even inhibits the activation of this MAP kinase $(97,98)$.

As mentioned above, in addition to JNK, a variety of protein kinases, including ERK, p38 kinase, casein kinase II, and PKC (99) can efficiently phosphorylate c-Jun $(90,100)$. Moreover, in some cell lines, ERK pathway seems to play a role in mediating some effects of IL-6 (98). However, blocking these kinases with specific inhibitors does not abrogate the stimulatory effect of IL-6 on c-Jun phosphorylation (Fig. 10A), AP1 binding to DNA (Fig. 10B) or MMP-13 gene expression (Fig. 10C). In a recent study (101), we blocked ERK with PD98059, p38 MAP kinase with SB203580, protein kinase C (PKC) with $\mathrm{H} 7$ and GF $109203 \mathrm{X}$, protein kinase A with H8 and H89, calmoduline-dependent protein kinase with calmidazolium, and phosphatidylinositol-3-kinase with wortmannin. Taken together, these results indicate that none of these protein kinases is likely required for the effect of IL-6 on MMP-13 gene expression.

Phosphorylation state of c-Jun is a dynamic process controlled by both serine/threonine protein kinases and protein phosphatases 2A (PP2A) (102). Therefore, the increase in phosphorylated c-Jun may result not only by an enhanced kinase activity but also by a reduced PP2A activity. In fact, a number of studies have clearly demonstrated that inhibition of protein phosphatases $2 \mathrm{~A}$ results in an induction of collagenase, JunB, and c-Fos mRNA and a potent activation of AP1, through serine/threonine phosphorylation (103-106). There are four classes of serine/threonine-specific protein phosphatases. These include PP1, PP2A, PP2B (calcineurin), and PP2C. PP2A and PP1 are widely distributed in the cytoplasm of mammalian cells and have been reported to be involved in signalling pathways, modifying the activity of a variety of protein kinases (107). Measurement of the PP2A activity in fibroblasts treated with increasing concentrations of IL-6 shows that this cytokine decreased this activity in a dose dependent fashion (Fig. 11A). Likewise, incubation of cells with $20 \mathrm{ng} / \mathrm{ml} \mathrm{IL-6}$ for 15 minutes to 24 hours resulted in a decrease in serine/threonine phosphatase activity, which was particularly marked between three and six hours. At 12 and 24 hours, this activity remained under the control activity (Fig. 11B). 


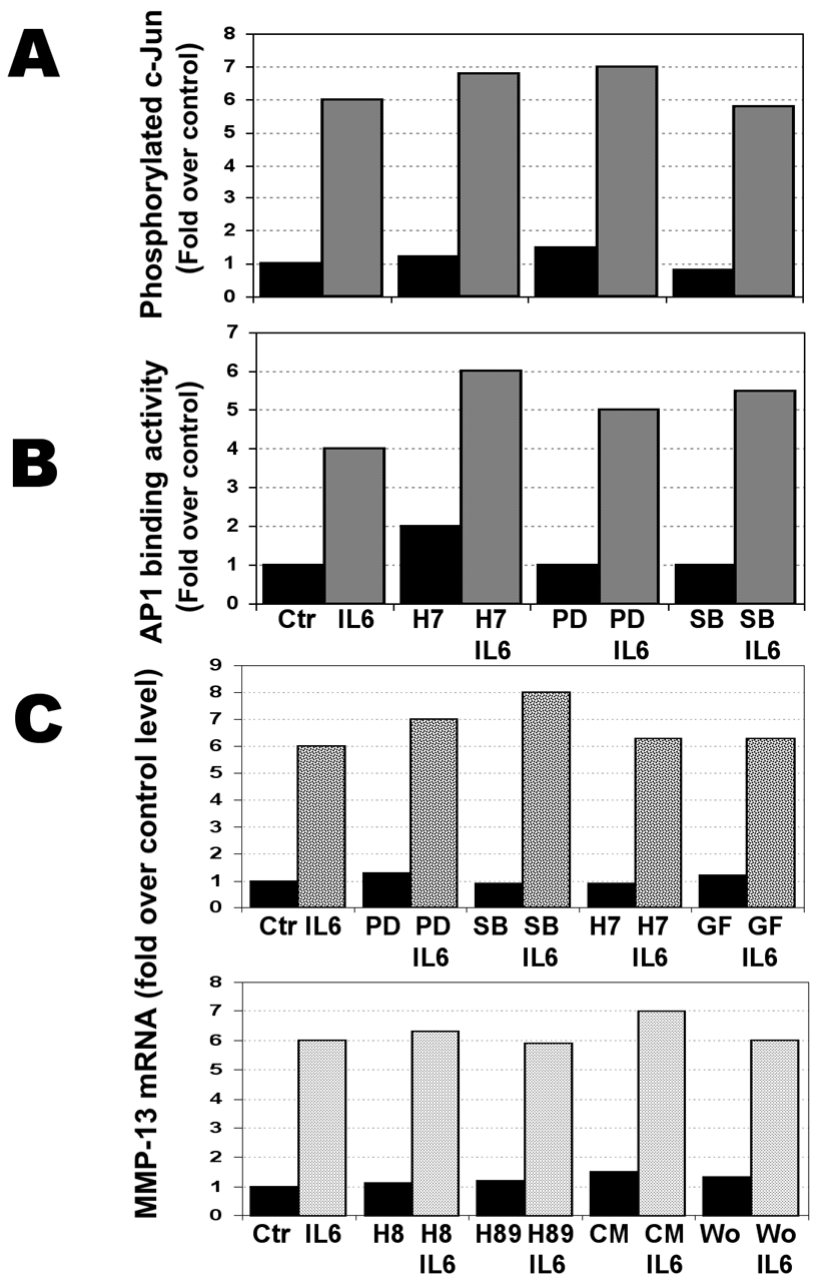

Fig. 10.- (A) IL-6-induced phosphorylation of c-Jun is not abrogated by the blockade of protein kinases. Twenty five micrograms of whole cell protein extracts from control cells (Ctr) or cells treated with $20 \mathrm{ng} / \mathrm{ml}$ IL-6 for 12 hours in the presence or absence of protein kinase inhibitors were separated as described in figure 8. Protein kinase C, ERK and p38 MAP kinase were inhibited with $20 \mu \mathrm{M} \mathrm{H7}$ (H7), $25 \mu \mathrm{M}$ PD98051 (PD), or $1 \mu \mathrm{M}$ SB203580 (SB). Immunoblot was probed with specific antiphosphorylated c-Jun antibody. (B) Blockade of protein kinases does not inhibit the effect of IL-6 on AP1 binding activity. We analyzed DNA binding activity by gel retardation assay. A double-stranded radiolabeled AP1 oligonucleotide was incubated with nuclear proteins extracted from control cells (Ctr) or cells treated with $20 \mathrm{ng} / \mathrm{ml} \mathrm{IL-6} \mathrm{(IL),} \mathrm{in} \mathrm{the} \mathrm{ab-}$ sence or presence of $20 \mu \mathrm{M} \mathrm{H7}(\mathrm{H7}), 25 \mu \mathrm{M}$ PD98051 (PD), or $1 \mu \mathrm{M}$ SB203580 (SB). Bars represent the intensity of the DNA binding in the different experimental conditions. (C) Steady-state levels of MMP-13 mRNA in fibroblasts treated with $20 \mathrm{ng} / \mathrm{ml} \mathrm{IL}-6$ in the absence or presence of a number of protein kinase inhibitors. Confluent Rat-1 fibroblasts were incubated for 24 hours in control medium (Ctr) or medium containing $20 \mathrm{ng} / \mathrm{ml} \mathrm{IL-6}$ in the presence or absence of protein kinase inhibitors [25 $\mu \mathrm{M}$ PD98051 (PD), $1 \mu \mathrm{M}$ SB203580 (SB), $20 \mu \mathrm{M} \mathrm{H7}, 10$ nM GF 109203X (GF), $20 \mu \mathrm{M}$ H8 and $50 \mathrm{nM}$ H89, $10 \mu \mathrm{M}$ calmidazolium (CM), and $0.1 \mu \mathrm{M}$ wortmannin (Wo)]. Protein kinase inhibitors were added to the cells 45 minutes before IL-6. mRNA was analyzed as described in figure 2 and autoradiograms were quantitated by scanning laser densitometry.

(A) La fosforilación de C-Jun provocada por la IL-6 no es evitada por el bloqueo de las quinasas de proteínas. Veinticinco microgramos de extracto proteico de células control (Ctr) o de células tratadas con $20 \mathrm{ng} / \mathrm{mL}$ de IL-6 durante 12 horas en presencia o ausencia de inhibidores de quinasas de proteínas fueron separadas como se describe en la figura 8. Las quinasas de proteínas PKC, ERK y p38 MAP quinasa fueron inhibidas con $20 \mu \mathrm{M}$ H7 (H7), 25 uM PD98051 (PD) o 1 uM SB203580 (SB). Los inmunoblots fueron revelados con anticuerpos específicos anti-cJun fosforilado. (B) El bloqueo de las quinasas de proteínas no inhibe los efectos de la IL-6 sobre la actividad fijadora del AP1. Analizamos la actividad fijadora del AP1 al ADN mediante el procedimiento de retraso en gel. Un oligonucleótido de AP1 marcado con 32P fue incubado con extractos nucleares de proteínas obtenidas de células controles (Ctr) o de células tratadas con $20 \mathrm{ng} / \mathrm{mL}$ de IL-6 (IL) en ausencia o presencia de 20 uM H7 (H7), 25 uM PD98051 (PD) o 1 uM SB203589 (SB). Las barras representan la intensidad de la unión de AP1 al ADN en las diferentes condiciones experimentales. (C) Niveles de ARNm de la MMP-13 en fibroblastos tratados con $20 \mathrm{ng} / \mathrm{mL}$ de IL-6 en ausencia o presencia de diversos inhibidores de quinasas de proteínas. Fibroblastos Rat-1 confluentes fueron incubados durante 24 horas en medio control (Ctr) o medio de cultivo con $20 \mathrm{ng} / \mathrm{mL}$ de $\mathrm{IL}-6$ en presencia o ausencia de inhibidores de quinasas de proteínas [25 $\mu M$ PD98051 (PD), $1 \mu M$ SB203580 (SB), $20 \mu \mathrm{M} \mathrm{H7,} 10 \mathrm{nM}$ GF 109203X (GF), $20 \mu \mathrm{M} \mathrm{H8}, 50$ nM H89, 10 uM calmidazolio (CM) y 0,1 uM wortmanina (Wo)]. Los inhibidores de quinasas fueron añadidos a las células 45 minutos antes de la IL-6. El ARNm fue analizado como se describe en la figura 2 y las autorradiografías fueron cuantificadas mediante densitometría láser.

The key role of PP2A in the IL-6-induced MMP-13 gene expression is also supported by experiments in which Rat-1 fibroblasts are pretreated for 20 minutes with $25 \mathrm{nM}$ okadaic acid, a potent inhibitor of protein phosphatase 1 and PP2A (108). In this experimental condition, MMP-13-mRNA levels increase markedly and the addition of $20 \mathrm{ng} / \mathrm{ml}$ IL- 6 for 24 hours does not modify this effect (Fig. 12). In contrast, as expected, inhibition of tyrosine phosphatases with $0.1 \mathrm{mM}$ pervanadate does not change the stimulatory effects of IL-6 on MMP-13 gene expression. Furthermore, okadaic acid mimics the effects of IL-6 on MMP-13 gene expression. Many other authors have shown these effects of the okadaic acid on MMP gene expression, as well as on c-Jun phosphorylation and AP1 binding activity $(105,109,110) . I_{2}^{\text {PP2A }}$, another potent inhibitor of PP2A, have produced similar effects (106). This decrease in PP2A activity is not due to a reduced amount of PP2A protein in fibroblasts exposed to IL-6. Thus, measurement of these levels in cell extracts from fibroblasts treated with $20 \mathrm{ng} / \mathrm{ml} \mathrm{IL-6}$ for three to sixteen hours demonstrates that this cytokine did not induce any change in intracellular PP2A levels.

Core structure of PP2A consists of complexes of three subunits $(102,111,112)$. A $36 \mathrm{kDa}$ catalytic C subunit (PP2AC) is complexed with a structural A subunit of 65 $\mathrm{kDa}$ (PP2A-A). This dimer is associated with a third, variable regulatory B subunit, that likely influences substrate specificity or cellular localization (102). The phosphorylation on tyrosine-307 at the C-terminus of the catalytic subunit of PP2A regulates phosphatases activity $(113,114)$. It is well known that this phosphorylation is 

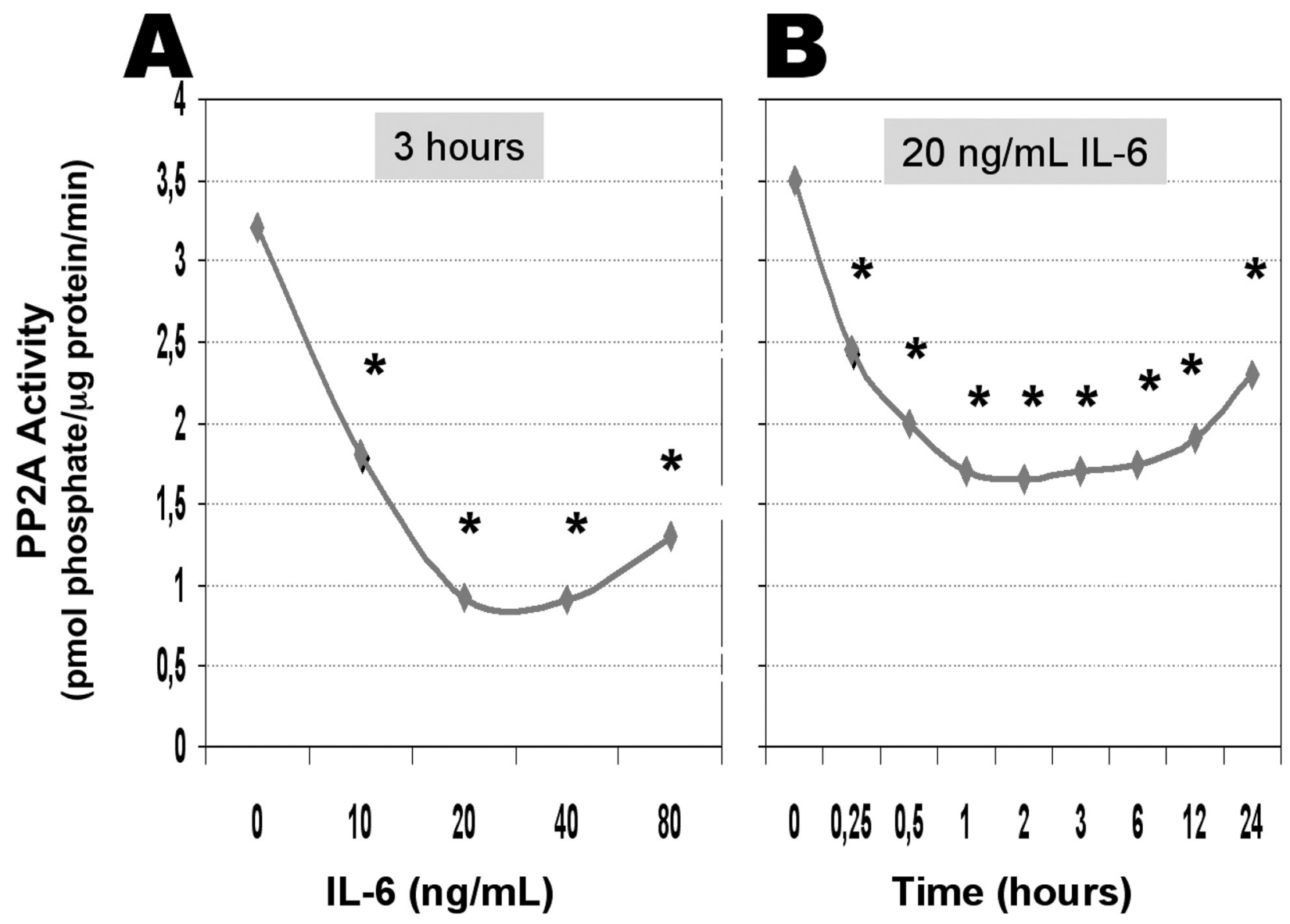

Fig. 11.- Effects of IL-6 on PP2A activity in cultured fibroblasts. (A) Dose-response curve. Rat-1 fibroblasts were incubated without and with 10 to 80 $\mathrm{ng} / \mathrm{ml} \mathrm{IL-6}$ for 3 hours. Phosphatase activity was assessed by the free phosphates released from the substrate (serine/threonine phosphopeptide) when incubated with cell lysates for 30 minutes. (B) Time-response curve. Cells were incubated with $20 \mathrm{ng} / \mathrm{ml} \mathrm{IL}-6$ for 15 minutes to 24 hours. *: p< 0.01 , as compared with the activity in control cells.

Efectos de la IL-6 sobre la actividad PP2A en cultivos de fibroblastos. (A) Curva de respuesta según la dosis. Fibroblastos Rat-1 fueron incubados sin y con 10 a $80 \mathrm{ng} / \mathrm{mL}$ de IL-6 durante 3 horas. La actividad fosfatasa fue determinada por los fosfatos libres desprendidos por el sustrato (fosfopéptido serina/treonina) cuando fue incubado con lisados celulares durante 30 minutos. (B) Curva de respuesta según el tiempo. Las células fueron incubadas con $20 \mathrm{ng} / \mathrm{mL}$ de IL-6 durante 15 minutos a 24 horas. *: $p<0,01$, comparado con la actividad en las células controles.

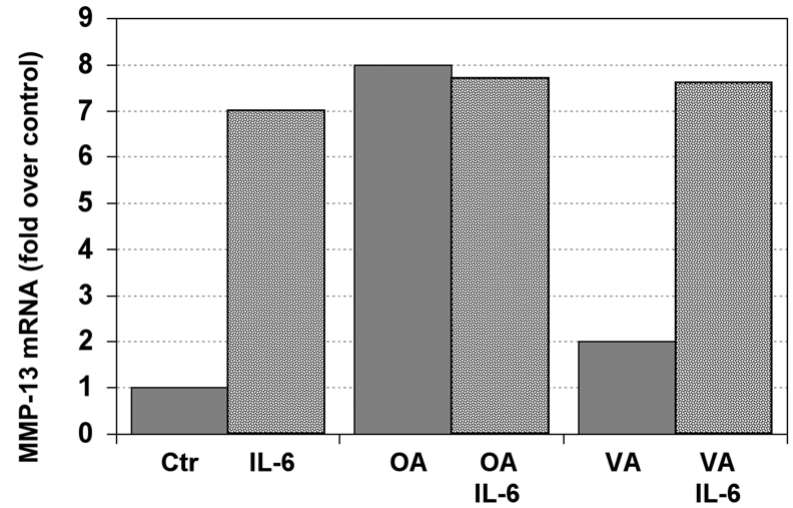

Fig. 12.- Okadaic acid reproduces the effect of IL-6 on MMP-13 mRNA. Confluent cells were incubated for 24 hours in control medium (Ctr) or medium containing $20 \mathrm{ng} / \mathrm{ml} \mathrm{IL-6.} \mathrm{Serine/threonine} \mathrm{phosphatases} \mathrm{were}$ inhibited with $25 \mathrm{nM}$ okadaic acid (OA) and tyrosine phosphatase with $0.1 \mathrm{mM}$ pervanadate (VA) added 20 minutes before IL-6. MMP-13 mRNA was analyzed by Northern blotting.

El ácido okadaico reproduce los efectos de la IL-6 sobre el ARNm de la MMP-13. Células confluentes fueron incubadas durante 24 horas en medio de control (Ctr) o en medio que contiene $20 \mathrm{ng} / \mathrm{mL}$ de $\mathrm{IL}-6$. Las fosfatasas serina/treonina fueron inhibidas con $25 \mathrm{nM}$ ácido okadaico (OA) y las fosfatasas de tirosinas con 0,1 mM de pervanadato (VA) añadidos a las células 20 minutos antes de la IL-6. El ARNm de la MMP-13 fue analizado mediante Northern blot.

associated with a $90 \%$ loss in activity, and thereby with a sustained effect of protein kinases $(113,115)$, including c-Jun phosphorylation. On the contrary, dephosphorylation of $\mathrm{PP} 2 \mathrm{~A}_{\mathrm{C}}$ reactivates this enzyme (102). Considering this mechanism of regulation of the PP2A activity, we 

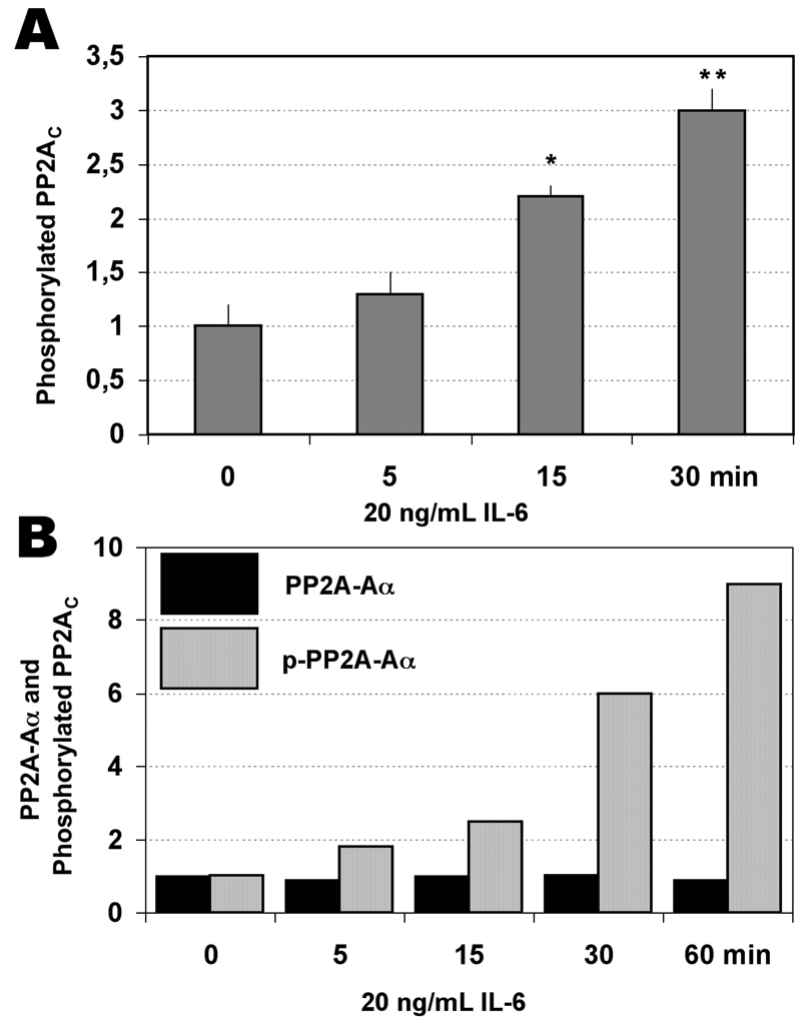

Fig. 13.- (A) Western blot analysis. Cells were incubated in the absence or presence of $20 \mathrm{ng} / \mathrm{ml}$ of IL- 6 for 5 to 30 minutes. Cell lysates were subjected to Western immunoblot analysis with anti-tyrosine 307 phosphorylated PP2A catalytic subunit antibody. ${ }^{*}: p<0.01 ;{ }^{*}: p<$ 0.001 . (B) Immunoprecipitation with anti-PP2A structural subunit antibody. Cells were treated with $20 \mathrm{ng} / \mathrm{ml}$ IL- 6 for 5 to 60 minutes. Cell lysates were immunoprecipitated with anti-PP2A structural subunit antibody and Western blotted either with anti-PP2A structural subunit antibody $(\square)$ or with anti-phosphotyrosine antibody $(\square)$. Bars represent phosphorylated PP2A catalytic subunit or PP2A structural subunit.

(A) Análisis por Western blot. Las células fueron incubadas en ausencia o presencia de $20 \mathrm{ng} / \mathrm{m} /$ de IL-6 durante 5 a 30 minutos. Los lisados celulares fueron sometidos a análisis por Western blot utilizando anticuerpos frente a la unidad catalítica de la PP2A fosforilada en la tirosina 307. ${ }^{*}: p<0,01 ;{ }^{* *}: p<0,001$. (B) Inmunoprecipitación de las proteínas celulares con anticuerpos frente a la subunidad estructural de la PP2A. Las células fueron tratadas con $20 \mathrm{ng} / \mathrm{mL}$ de $1 \mathrm{~L}-6$ durante 5 a 60 minutos. Los lisados celulares fueron inmunoprecipitados con anticuerpos frente a la subunidad estructural de la PP2A y posteriormente revelados con anticuerpos bien frente a la misma subunidad de la PP2A

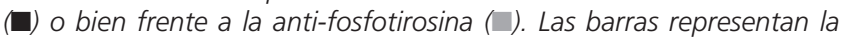
subunidad fosforilada de la PP2A o la subunidad estructural PP2A.

could hypothesize that binding of IL-6 to specific receptors on cell surface might inactivate PP2A by increasing tyrosine phosphorylation on its catalytic subunit which, in turn, would prolong activation of AP1. Similar sequence of events has been shown following addition of insulin to skeletal muscle cells $(115,116)$. Moreover, inhibition of PP2A with $\mathrm{I}_{2}^{\mathrm{PP} 2 \mathrm{~A}}$ increased both the concentration and DNA binding of c-Jun and the transcriptional ac- tivity of AP1 (106). Likewise, PP2A inhibitors induce threonine phosphorylation of STAT3, other cytoplasmic transcription factor that upon activation translocate into the nucleus where they activate target genes $(117,118)$.

Western blot analysis using specific polyclonal antityrosine 307 phosphorylated $\mathrm{PP}^{2} \mathrm{~A}_{\mathrm{C}}$ antibody shows a marked increase in the tyrosine phosphorylation of $\mathrm{PP}_{2} \mathrm{~A}_{\mathrm{C}}$ (Fig. 13A). On the other hand, while immunoprecipitation of PP2A using specific antibody against the structural subunit of PP2A demonstrates that IL-6 did not affect to the total amount of this subunit, immunodetection of tyrosine phosphorylated proteins with antiphosphotyrosine antibody indicates that treatment of cells with $20 \mathrm{ng} / \mathrm{mL}$ IL- 6 for 0 to 60 minutes induces a timedependent increase in the $\mathrm{PP} 2 \mathrm{~A}_{\mathrm{C}}$ tyrosine phosphorylation (Fig. 13B). This result concurs with those reported by Choi et al. (119), who also found that IL-6 induced PP2A tyrosine phosphorylation.

IL-6 initiates its actions by binding to a specific receptor complex on the cell membrane. This complex is composed of two subunits: an $80-\mathrm{kDa}$ binding protein and a 130-kDa transmembrane signal transducting component (gp130) (48). Other members of the IL-6 cytokine superfamily (IL-11, oncostatin M, leukemia inhibitory factor, ciliary neutrophic factor, cardiotropin-1, neutrophin1/B.cell stimulating factor-3) (120-122) share the same gp130 receptor subunit. Activation of IL-6 signal transduction involved gp130-homodimerization and tyrosine phosphorylation of the cytoplasmic tail of gp130 by gp130-associated Janus tyrosine kinases (JAKs). These kinases are recruited to the plasma membrane and activated upon cell activation by cytokines and growth factors (123). All JAKs contain at least one copy of a peptide sequence, which is part of a consensus for PP2A binding $(124,125)$. This phosphatase has been shown to form stable complexes with various protein kinases, including Jak2 $(115,126,127)$. Thus, it is conceivable that the IL-6-induced PP2A $\mathrm{A}_{\mathrm{c}}$ phosphorylation and PP2A inactivation might be mediated by Jak2. Thus, as figure 14 shows, pre-treatment of cells for 60 minutes with $5 \mu \mathrm{M}$ AG490, a specific inhibitor of Jak2 (128), abrogates completely the IL-6-induced increase in MMP-13 mRNA, binding of nuclear proteins to AP1 consensus sequence, c-Jun and $\mathrm{PP} 2 \mathrm{~A}_{\mathrm{c}}$ phosphorylation, and $\mathrm{PP} 2 \mathrm{~A}$ activity. As far as we are aware, no further information is available on the role of Jak kinases and PP2A in mediating the effect of IL-6 on MMP-13 gene expression. However, oncostatin M, another member of IL-6 superfamily cytokine (122), also induces MMP gene expression in astrocytes, fibroblasts and osteoblasts $(37,130)$, and this effect is associated with Jak1 and Jak2 tyrosine phosphorylation.

Thus, we can conclude that, at least "in vitro", IL-6 is an antifibrogenic cytokine that might contribute to remodelling connective tissue. IL-6 increases MMP-13 gene expression acting at transcriptional level via AP1. IL-6 increases $c$-jun and $c$-fos gene expression, enhances 


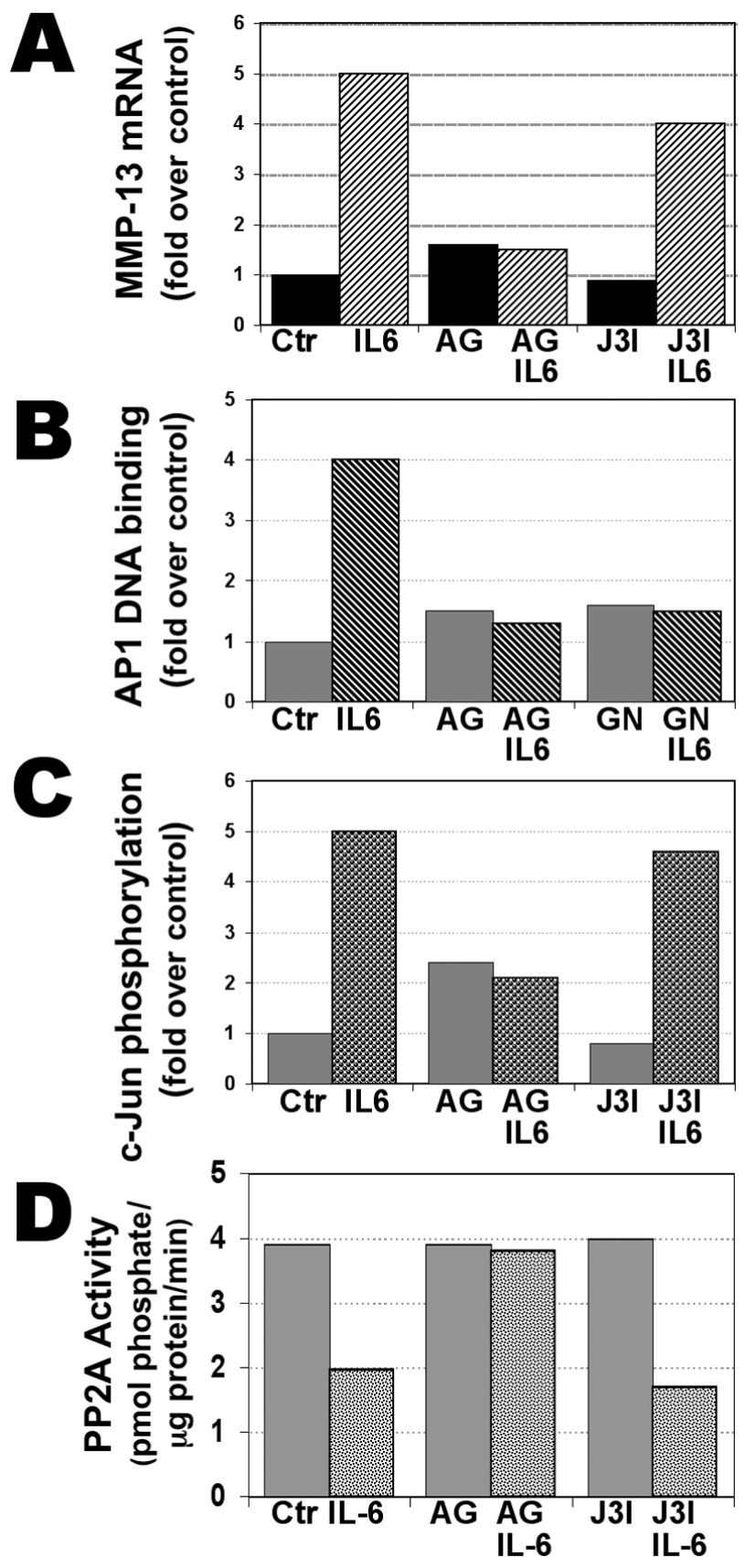

Fig. 14.- Inhibition of Jak2 abrogates the effects of IL-6 on MMP-13 mRNA (A), AP1 binding activity (B), c-Jun serine phosphorylation (C), and PP2A activity (D). (Panel $A$ ) Cells were incubated for 24 hours in control medium (Ctr) or medium containing $20 \mathrm{ng} / \mathrm{mL} \mathrm{IL}-6,20 \mathrm{ng} / \mathrm{mL}$ IL-6 plus $5 \mu \mathrm{M}$ AG490 (AG), $5 \mu \mathrm{M}$ AG490, $20 \mathrm{ng} / \mathrm{mL}$ IL-6 plus 135 $\mu \mathrm{g} / \mathrm{mL}$ genistein (Gen), $135 \mathrm{mg} / \mathrm{mL}$ genistein. AG490 and genistein were added to the cells 60 minutes before IL-6. MMP-13 mRNA was analyzed by Northern blotting. Bars represent steady-state MMP-13 mRNA levels in cells cultured in these conditions. (Panel B) Cells were incubated for 12 hours without or with $20 \mathrm{ng} / \mathrm{mL}$ IL-6 in the absence or presence of $5 \mu \mathrm{M} A G 490(A G)$, or $135 \mathrm{mg} / \mathrm{mL}$ genistein (GN). DNA binding was analyzed by gel retardation assay. Ctr, control cells. (Panel C) Cells were treated for 30 minutes with $20 \mathrm{ng} / \mathrm{mL} \mathrm{IL}-6$ in the absence or presence of $5 \mu \mathrm{M}$ AG490, $100 \mu \mathrm{M}$ of JAK3 Inhibitor I (J3I) added 60 minutes before IL-6. Twenty-five micrograms of protein extracts from cells treated as indicated were subjected to Western immunoblot analysis with anti-tyrosine 307 phosphorylated PP2A catalytic subunit antibody $\left(\mathrm{p}-\mathrm{PP} 2 \mathrm{~A}_{\mathrm{c}}\right)$. (Panel D) Cells were incubated for three hours in the same experimental conditions as in panel A. PP2A activity in cell lysates was assessed as described in figure 11. Ctr, Control cells. La inhibición de JAK2 anula los efectos de la IL-6 sobre el ARNm de la MMP-13 (A), la actividad de la AP1 (B), la fosforilación de serina en el c-Jun (C) y la actividad de la PP2A (D). (Panel A) Las célula fueron incubadas durante 24 horas en medio de control (Ctr) o en medio que contenía $20 \mathrm{ng} / \mathrm{mL}$ de IL-6, $20 \mathrm{ng} / \mathrm{mL}$ de IL-6 más 5 uM AG490 (AG), 5 uM AG490, $20 \mathrm{ng} / \mathrm{mL} \mathrm{IL}-6$ más $135 \mu \mathrm{g} / \mathrm{mL}$ genisteína (Gen), $135 \mu \mathrm{g} / \mathrm{mL}$ genisteína. El AG490 y la genisteína fueron añadidos a las células 60 minutos antes del IL-6. El ARNm MMP-134 fue analizado mediante Northern blot. Las barras representan los niveles de ARNm MMP-13 en las células cultivadas en las condiciones mencionadas. (Panel B) Las células fueron cultivadas durante 12 horas con o $\sin 20 \mathrm{ng} / \mathrm{mL}$ de $/ \mathrm{L}-6$ en ausencia o presencia de $5 \mu \mathrm{M}$ AG490 (AG) o $135 \mu \mathrm{g} / \mathrm{mL}$ genisteína (GN). La unión al ADN fue analizada mediante la prueba del retardo en gel. Ctr, células controles. (Panel C) Las células fueron tratadas durante 30 minutos con $20 \mathrm{ng} / \mathrm{mL}$ en ausencia o presencia de $5 \mathrm{mM}$ AG490, $100 \mu \mathrm{M}$ del Inhibidor de JAK3 (J3I) añadidos a las células 60 minutos antes de la IL-6. Veinticinco microgramos de extracto proteico de células tratadas como se ha indicado fueron sometidos a análisis por Western blot con anticuerpos frente a la subunidad catalítica de la PP2A fosforilada en la tirosina. (Panel D) El bloqueo de JAK2 impide la fosforilación de la subunidad catalítica de PP2A y la pérdida de la actividad PP2A. Las células fueron incubadas durante tres horas en las mismas condiciones experimentales que se mencionan en panel $A$. La actividad PP2A en los lisados celulares fue determinada como se describe en la figura 11. Ctr, células controles.

phosphorylated c-Jun, and promotes the binding of AP1 to the MMP-13 promoter. The increase in phosphorylated c-Jun is not due to increased protein kinase activity, including Jun N-terminal kinase, but to a decreased serine/threonine phosphatases activity. IL-6, after binding to a specific receptor on the cell membrane, activates tyrosine kinase JAK2, which phosphorylates the catalytic subunit of protein phosphatases 2A (PP2A) at the tyrosine 307 leading to inhibition of its activity and prolongs c-Jun phosphorylation (Fig. 15).

\section{REFERENCES}

1. Orrego H, Blendis LM, Crossley IR, Medline A, Macdonald A, Ritchie S, et al. Correlation of intrahepatic pressure with collagen in the Disse space and hepatomegaly in humans and in the rat. Gastroenterology 1981; 80: 546-56.

2. Horn T, Christoffersen P, Henriksen JH. Alcoholic liver injury: defenestration in noncirrhotic liver- a scanning electron microscopic study. Hepatology 1987; 7: 77-82.

3. Schuppan D, Ruehl M, Somasundaram R, Hahn EG. Matrix as a modulator of hepatic fibrogenesis. Semin Liv Dis 2001; 351-72.

4. Rojkind M, Greenwel P. The liver as a bioecological system. In: Arias IM, Jakoby WB, Popper H, Schachter D, Shafritz DA, eds. "The liver: Biology and Pathology". 2nd ed. New York: Raven Pres Ltd. 1988. p. 707-16.

5. Rojkind M, Giambrone MA, Biempica L. Collagen type in normal and cirrhotic liver. Gastroenterology 1970; 76: 710-9.

6. Friedman SL. Molecular regulation of hepatic fibrosis, an integrated cellular response to tissue injury. J Biol Chem 2000; 275: 2247-50. 


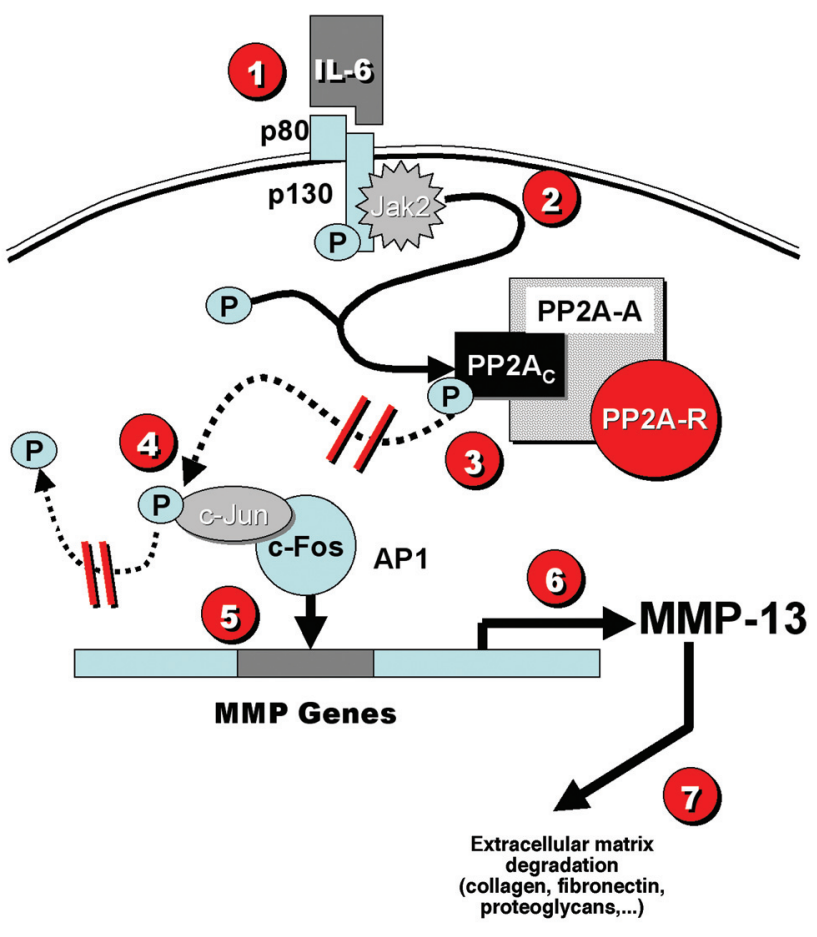

Fig. 15.- After IL-6 binding to specific receptor (gp80) on the cell membrane (1), tyrosine kinase Jak2 phosphorylates and activates the transmembrane signal transducting component of the IL-6 receptor (gp130) (2). Afterward, Jak2 binds and phosphorylates tyrosine 307 in the catalytic subunit of PP2A (3), which is associated with a lost of its phosphatases activity (4). Because of this low serine/threonine phosphatases activity, c-Jun remains phosphorylated for a longer period of time and contributes to maintain activation of the MMPs gene expression (5) and MMPs synthesis (6). This enhanced MMP proteins and MMP activity might result in the degradation of extracellular matrix, the hepatic stellate cell death by apoptosis, and in the fibrosis remodelling (7).

Tras la unión de la IL-6 a los receptores especificos (gp80) situados en la membrana plasmática de las células (1), la quinasa de proteínas JAK2 fosforila y activa al componente transmembranoso de transmisión de señal de la IL-6 (gp130) (2). Tras ello, JAK2 se une y fosforila a la tirosina 307 de la unidad catalítica de la PP2A (3), lo cual se encuentra asociado con una pérdida de su actividad catalítica (4). Debido a esta baja actividad fosfatasa sobre serinas/treoninas, el c-Jun permanece fosforilado durante más tiempo y contribuye a mantener la activación de la expresión genética de la MMP-13 (5) y la síntesis de la MMP-13 (6). Este aumento de las MMPs y de la actividad de la MMP puede determinar la degradación de la matriz extracelular, la muerte por apoptosis de las células estrelladas del hígado y el remodelamiento de la fibrosis (7).

7. Blomhoff R, Wake K. Perisinusoidal stellate cells of the liver: important roles in retinal metabolism and fibrosis. FASEB J 1991; 5: 2717.

8. Kingsley DM, The TGF $\beta$ superfamily: a new members, new receptors, and new genetic tests of function in different organisms. Genes Dev 1994; 8: 133-46.

9. Friedman SL. Cytokines and fibrogenesis. Semin Liv Dises 1999; $129-40$.

10. Geerts A, Vrijsen R, Rauterberg J, Burt A, Schellinck P, Wisse E. In vitro transition of fat-storing cells to myofibroblast-like cells parallels marked increase of collagen synthesis and secretion. J Hepatol 1989; 9: 59-68.

11. Abdel-Aziz G, Lebeau G, Rescan PY, Clement B, Rissel M, Deug- nier Y, et al. Reversibility of hepatic fibrosis in experimentally induced cholestasis in rat. Am J Pathol 1990; 137: 1333-43.

12. Morcos SH, Khayyal MT, Mansour MM, Saleh S, Ishak EA, Girgis NI, et al. Reversal of hepatic fibrosis after praziquantel therapy of murine schistosomiasis. Am Soc Trop Med Hygiene 1985; 34: 314-21.

13. Schiff ER, Heathcote J, Dienstag JL, et al. Improvements in liver histology and cirrhosis with extended lamivudine therapy. Hepatology 2000; 32: 296 (Abstract).

14. Hammel P, Couvelard A, O'Toole D, Ratouis A, Sauvanet A, Flejou $\mathrm{JF}$, et al. Regression of liver fibrosis after biliary drainage in patients with chronic pancreatitis and stenosis of the common bile duct. $\mathrm{N}$ Engl J Med 2001; 344: 418-23.

15. Wanless IR, Nakashima E, Sherman M. Regression of human cirrhosis. Morphologic features and the genesis of incomplete septal cirrhosis. Arch Pathol Lab Med 2000; 124: 1599-607.

16. Iredale JP. Hepatic stellate cell behaviour during resolution of liver injury. Semin Liver Dis 2001; 21: 427-36.

17. Wanless IR, Nakashima E, Sherman M. Regression of human cirrhosis. Morphologic features and the genesis of incomplete septal cirrhosis. Arch Pathol Lab Med 2000; 124: 1599-607.

18. Issa R, Zhou X, Constandinou CM, Fallowfield J, Millward-Sadler $\mathrm{H}$, Gaca MDA, et al. Spontaneous recovery from micronodular cirrhosis: evidence for incomplete resolution associated with matrix cross-linking. Gastroenterology 2004; 126: 1795-808.

19. Zavalova L. Enzymes from the medicinal leech (Hirudo medicinalis) coding for the unusual enzymes that specifically cleave endoepsi (gamma-glut) lys isopeptide bonds and help to dissolve blood clots. Mol Cell Genet 1996; 253: 20-5.

20. Arthur MJ. Collagenases and liver fibrosis. J Hepatol 1995; 22: 44-8.

21. Iimuro Y, Nishio T, Morimoto T, Nitta T, Stefanovic B, Choi SK, et al. Delivery of matrix metalloproteinase-1 attenuates established liver fibrosis in the rat. Gastroenterology 2003; 124: 445-58.

22. Emonard H, Grimaud JA. Matrix metalloproteinases. Cell Mol Biol 1990; 36: 131-53.

23. Mengshol JA, Mix KS, Brinckerhoff CE. Matrix metalloproteinases as therapeutic targets in arthritis diseases. Arthritis Rheum 2002; 46: 13-20.

24. Nagase H, Woessner JF Jr. Matrix metalloproteinases. J Biol Chem 1999; 274: 21491-4.

25. Knäuper V, Cowell S, Smith B, López-Otín C, O'Shea M, Morris H, et al. The role of the terminal domain of human collagenase- 3 (MMP-13) in the activation of procollagenase-3, substrate specificity, and tissue inhibitor of metalloproteinase interaction. J Biol Chem 1997; 272: 7608-16.

26. Mauviel A. Cytokine regulation of metalloproteinase gene expression. J Cell Biochem 1993; 53: 288-95.

27. Arthur MJP, Iredale JP, Mann DA. Inhibitors of metalloproteinases: role in liver fibrosis and alcoholic liver disease. Alcohol Clin Exp Res 1999; 23: 940-3.

28. Howard EW, Banda MJ. Binding of tissue inhibitor of metalloproteinases 2 to two distinct sites on human 72-kDa gelatinase. J Biol Chem 1991; 266: 17972-7.

29. Murphy FR, Issa R, Zhou X, Ratnarajah S, Nagase H, Arthur MJ, et al. Inhibition of apoptosis od activated hepatic stellate cells by tissue inhibitor of metalloproteinase-I is mediated via effects on matrix metalloproteinase inhibition. Implications for reversibility of liver fibrosis. J Biol Chem 2002; 277: 11069-76.

30. Murphy F, Waung J, Collins J, Arthur MJ, Nagase H, Mann D, et al. $\mathrm{N}$-Cadherin cleavage during activated hepatic stellate cell apoptosis is inhibited by tissue inhibitor of metalloproteinase-1. Comp Hepatol 2004; 3 (Supl. 1): S8.

31. Knittel T, Mehde M, Grundmann A, Saile B, Scharf JG, Ramadori G. Expression of matrix metalloproteinases and their inhibitors during hepatic tissue repair in the rat. Histochem Cell Biol 2000; 113: 443-53.

32. Trim JE, Samra SK, Arthur MJ, Wright MC, McAulay M, Beri R, et al. Upstream tissue inhibitor of metalloproteinases-1 (TIMP-1) element-1, a novel and essential regulatory DNA motif in the human TIMP-1 gene promoter, directly interacts with a $30-\mathrm{kDa}$ nuclear protein. J Biol Chem 2000; 275: 6657-63.

33. Siwik DA, Chang DL-F, Colucci WS. Interleukin-1 $\beta$ and tumor necrosis factor- $\alpha$ decrease collagen synthesis and increase matrix metalloproteinase activity in cardiac fibroblasts in vitro. Cir Res 2000; 86: 1259-65. 
34. Wang SC, Ohata M, Schrum L, Rippe RA, Tsukamoto H. Expression of interleukin-10 by in vitro and in vivo activated hepatic stellated cells. J Biol Chem 1998; 273: 302-8.

35. Brenner DA, O'Hara M, Angel P, Chojkier M, Karin M. Prolonged activation of jun and collagenase genes by tumor necrosis factor- $\alpha$. Nature 1989; 337: 661-3.

36. Delany AM, Jeffrey JJ, Canalis E. Cortisol increases interstitial collagenase expression in osteoblasts by post-transcriptional mechanisms. J Biol Chem 1995; 270: 26607-12.

37. Varghese S, Yu K, Canalis E. Leukemia inhibitory factor and oncostatin M stimulate collagenase-3 expression in osteoblasts. Am J Physiol 1999; 276: 465-71.

38. Onodera S, Nishihira J, Iwabuchi K, Koyama Y, Yoshida K, Tanaka $\mathrm{S}$, et al. Macrophage migration inhibitory factor up-regulates matrix metalloproteinase-9 and -13 in rat osteobasts. J Biol Chem 2002; 277: 7865-74

39. Gazzero E, Rydziel S, Canalis E. Skeletal bone morphogenetic proteins suppress the expression of collagenase- 3 by rat osteoblasts. Endocrinology 1999; 140: 562-7.

40. Van den Berg WB. Pathophysiology of osteoarthritis. Joint Bone Spine 2000; 67: 555-6.

41. Knittel T, Mehde M, Kobold D, Saile B, Dinter C, Ramadori G. Expression patterns of matrix metalloproteinases and their inhibitors in parenchymal and nonparenchymal cells of rat liver: regulation by TNF- $\alpha$ and TGF- $\beta 1$. J Hepatol 1999; 30: 48-60.

42. Herbst H, Wege T, Milani S, Pellegrini G, Orzeckowski HD, Bechstein WO, et al. Tissue inhibitor of metalloproteinase-1 and -2 RNA expression in rat and human liver fibrosis. Am J Pathol 1997; 150: 1647-59.

43. Rieder H, Armbrust T, Meyer zum Buschenfelde KH, Ramadori G. Contribution of sinusoidal endothelial liver cells to liver fibrosis: expression of transforming growth factor-beta 1 receptors and modulation of plasmin-generating enzymes by transforming growth factorbeta 1. Hepatology 1993; 18: 937-44.

44. Sakaida I, Uchida K, Matsumura Y, Okita K. Interferon gamma treatment prevents procollagen gene expression without affecting transforming growth factor-b1 expression in pig serum-induced rat liver fibrosis in vivo. J Hepatol 1998; 28: 471-9.

45. Li YY, McTiernan CF, Feldman AM. Proinflammatory cytokines regulate tissue inhibitors of metalloproteinases and disintegrin metalloproteinase in cardiac cells. Cardiovasc Res 1999; 42: 162-72.

46. Arai M, Niioka M, Maruyama K, Wada N, Fujimoto N, Nomiyama $\mathrm{T}$, et al. Changes in serum levels of metalloproteinases and their inhibitors by treatment of chronic hepatitis $\mathrm{C}$ with interferon. Dig Dis Sci 1996; 41: 995-1000.

47. Mitsuda A, Suou T, Ikuta Y, Kawasaki H. Changes in serum tissue inhibitor of matrix metalloproteinase- 1 after interferon alpha treatment in chronic hepatitis C. J Hepatol 2000; 32: 666-72.

48. Hirano T. Interleukin-6 and its receptor: ten year later. Int Rev Immunol 1998; 16: 249-84.

49. Taga T, Kishimoto T. Human cytokines. In: Aggarwal BB, Gutterman JU, eds. Handbook for basic and clinical research. Oxford, United Kingdom: Blackwell Scientific Publications, 1992. p. 144-63.

50. Thiele DL. Tumor necrosis factor, the acute phase response and the pathogenesis of alcoholic liver disease. Hepatology 1989; 9: 497-9.

51. Sweeting J. Tumor necrosis factor in alcoholic hepatitis. Gastroenterology 1989; 97: 1056-7.

52. Deviere J, Content J, Denys C, Vandenbussche P, Le Moine O, Schandene L, et al. Immunoglobulin A and interleukin 6 form a positive secretory feedback loop: a study of normal subjects and alcoholic cirrhotics. Gastroenterology 1992; 103: 1296-301.

53. Díez-Ruiz A, Santos-Pérez JL, López-Martínez G, González-Calvín J, Gil-Estremera B, Gutiérrez-Gea F. Tumor necrosis factor, interleukin-1 and interleukin-6 in alcoholic cirrhosis. Alcohol Alcohol 1993; 28: 319-23.

54. Khoruts A, Stahnke L, McClain CJ, Logan G, Allen JI. Circulating tumor necrosis factor, interleukin- 1 and interleukin- 6 concentrations in chronic alcoholic patients. Hepatology 1991; 13: 267-76.

55. Barber MD, Fearon KC, Ross JA. Relationship of serum levels of interleukin-6, soluble interleukin-6 receptor and tumor necrosis factor receptors to the acute-phase protein response in advanced pancreatic cancer. Clin Sci (Lond) 1999; 96: 83-7.

56. Houssiau FA, Devogelaer JP, Van Damme J, de Deuxchaisnes CN,
Van Snick J. Interleukin-6 in synovial fluid and serum of patients with rheumatoid arthritis and other inflammatory arthritides. Arthritis Rheum 1988; 31: 784-7.

57. Solis-Herruzo JA, Rippe RA, Schrum LW, De la Torre P, García I, Jeffrey JJ, et al. Interleukin-6 rat metalloproteinase-13 gene expression through stimulation of activator protein 1 transcription factor in cultured fibroblasts. J Biol Chem 1999; 274: 30919-26.

58. Franchimont N, Rydziel S, Delany AM, Canalis E. Interleukin-6 and its soluble receptor cause a marked induction od collagenase 3 expression in rat osteoblest cultures. J. Biol. Chem 1997; 272: 1214450.

59. Kusano K, Miyaura C, Inada M, Tamura T, Ito A, Nagase H, et al. Regulation of matriz metalloproteinases (MMP-2, -3, -9, and -13) by interleukin-1 and interleukin-6 in mouse calvaria: association of MMP induction with bone resorption. Endocrinology 1998; 139: 1338-45.

60. Shingu M, Nagai Y, Isayama T, Naono T, Nobunaga M, Nagai Y. The effects of cytokines on metalloproteinase inhibitors (TIMP) and collagenase production by human chondrocytes and TIMP production by synovial cells and endothelial cells. Clin Exp Immunol 1993; 94: 145-9.

61. Lotz M, Guerne PA. Interleukin-6 induces the synthesis of tissue inhibitor of metalloproteinases-1/erythroid potentiating activity (TIMP1/EPA). J Biol Chem 1991; 266: 2017-20.

62. Sato T, Ito A, Mori Y. Interleukin-6 enhances the production of tissue inhibitor of metalloproteinases (TIMP) but not that of matrix metalloproteinases by human fibroblasts. Biochem Biophys Res Commun 1990; 170: 824-9.

63. Silacci P, Dayer JM, Desgeorges A, Peter R, Manueddu C, Guerne PA. Interleukin (IL)-6 and its soluble receptor induce TIMP-1 expression in synoviocytes and chondrocytes, and block IL-1-induced collagenolytic activity. J Biol Chem 1998; 273: 13625-9.

64. Richards CD, Shoyab M, Brown TJ, Gauldie J. Selective regulation of metalloproteinase inhibitor (TIMP-1) by oncostatin $\mathrm{M}$ in fibroblasts in culture. J Immunol 1993; 150: 5596-608.

65. Edwards DR, Rocheleau H, Sharma RR, Wills AJ, Cowie A, Hassel $\mathrm{JA}$, et al. Involment of AP1 and PEA3 binding site in the regulation of murine tissue inhibitor of metalloproteinases-1 (TIMP-1) transcription. Biochim Biophys Acta 1992; 1171: 41-55.

66. Matrisian LM, Glaichenhaus N, Gesnel MC, Breathnach R. Epidermal growth factor and oncogenes induce transcription of the same cellular mRNA in rat fibroblasts. EMBO J 1985; 4: 1435-40.

67. Pendás AM, Balbín M, Llano E, Jiménez MG, López-Otín C. Structural analysis and promoter charactarization of the human collagenase-3 gene (MMP-13). Genomics 1997; 40: 222-33.

68. Collier IE, Smith J, Kronberger A, Bauer EA, Wilhelm SM, Eisen $\mathrm{AZ}$, et al. The structure of the human skin fibroblast collagenase gene. J Biol Chem 1988; 263: 10711-3.

69. Fini ME, Plucinska IM, Mayer AS, Gross RH, Brinckerhoff CE. A genes for rabbit synovial cell collagenase: member of a family of metalloproteinases that degrade the connective tissue matrix. Biochemistry $1987 ; 26$ : 6156-65.

70. Belaaouaj A, Shipley JM, Kobayashi DK, Zimonjic DB, Popescu N, Silverman GA, et al. Human macrophage metalloelastase. Genomic organization, cjromosomal lacation, gene linkage, and tissue-specific expression. J Biol Chem 1995; 270: 14568-75.

71. Rajakumar RA, Quinn CO. Parathyroid hormone induction of rat interstitial collagenase mRNA in osteosarcoma cells is mediated through an AP-1-binding site. Mol Endo 1996; 10: 867-78.

72. Huhtala P, Tuuttila A, Chow LT, Lohi J, Keski-Oja J, Tryggvason K. Complete structure of the human gene for 92-kDa type IV collagenase. Divergent regulation of expression for the 92- and 72- kilodalton enzyme genes in HT-1080 cells. J Biol Chem 1991; 266: 1648590.

73. Gaire M, Magbanua Z, McDonnell S, McNeil L, Lovett DH, Matrisian LM. Structure and expression of the human gene for the matrix metalloproteinase matrilysin. J Biol Chem 1994; 269: 2032-40.

74. Tardif G, Pelletier JP, Dupuis M, Hambor JE, Martel-Pelletier J. Cloning, sequencing and characterization of the 5'-flaking region of the human collagenase-3 gene. Biochem J 1997; 323: 13-6.

75. Selvamurugan N, Chou WY, Pearman AT, Pulumati MR, Partridge NC. Parothyroid hormone regulates the rat collagenase- 3 promoter in osteoblastic cells through the cooperative interaction of the activator 
protein-1 site and the runt domain binding sequence. J Biol Chem 1998; 273: 10647-57.

76. Angel P, Baumann I, Stein B, Delius H, Rahmsdorf HJ, Herrlich P. 12-O-tetradecanoyl-phorbol-13-acetate induction of the human collagenase gene is mediated by an inducible enhancer element located in the 5'-flaking region. Mol Cell Biol 1987; 7: 2256-66.

77. Borden P, Solymar D, Sucharczuk A, Lindman B, Cannon P, Heller RA. Cytokine control of interstitial collagenase and collagenase-3 gene expression in human chondrocytes. J Biol Chem 1996: 271: 23577-81.

78. Daffada AA, Murray EJ, Young SP. Control of activator protein-1 and nuclear factor kappa B activity by interleukin-1, interleukin-6 and metals in HEPG2 cells. Biochim Biophys Acta 1994; 1222: 23440.

79. Melamed D, Resnitzky D, Haimov I, Levy N, Pfarr CM, Yaniv M, et al. Interleukin 6 induces DNA binding activity of AP1 in M1 myeloblastic cells but not in a growth resistant cell derivative. Cell Growth Differ 1993; 4: 689-97.

80. Karin M. The regulation of AP-1 activity by mitogen-activated protein kinases. J Biol Chem 1995; 270: 16483-6.

81. Trenies I, Paterson HF, Hooper S, Wilson R, Marshall CJ. Activated MEK stimulates expression of AP1 components independently of phosphatidylinositol 3-kinase (PI3-kinase) but requires a PI3-kinase signal to stimulate DNA synthesis. Mol Cell Biol 1999; 19: 321-9.

82. Brown RT, Ades IZ, Nordan RP. An acute phase response factor/NFka ppa B site downstream of the junB gene that mediates responsiveness to interleukin-6 in a murine plasmacytoma. J Biol Chem 1995; 270: 31129-35.

83. Wang Y, Fuller, GM. Interleukin-6 and ciliary neurotrophic factor trigger janus kinase activation and early gene response in rat hepatocytes. Gene 1995; 162: 285-9.

84. Lütticken C, Coffer P, Yuan J, Schwartz C, Caldenhover E, Schindler C, et al. Interleukin-6-induced serine phosphorylation of transcription factor APRF: evidence for a role in interleukin-6 target gene induction. FEBS letters 1995; 360: 137-43.

85. Jenab S, Morris PL. Transcriptional regulation of Sertoli cell immediate early genes by interleukin- 6 and interferon-gamma is mediated through phosphorylation of STAT-3 and STAT-1 proteins. Endocrinology 1997; 138: 2740-6.

86. Kojima H, Nakajima K, Hirano T. IL-6-inducible complexes on an IL-6 response element of the junB promoter contain Stat3 and 36 kDa CRE-like site binding protein(s). Oncogene 1996; 12: 547-54.

87. Cressman DE, Greenbaum LE, DeAngelis RA, Ciliberto G, Furth $\mathrm{EE}$, Poli V, et al. Liver failure and defective hepatocyte regeneration in interleukin-6-deficient mice Science 1996; 274: 1379-83.

88. Chang L, Karin M. Mammalian MAP kinase signalling cascades. Nature 2001; 410: 37-40.

89. Ahmed S, Rahman A, Hasnain A, Goldberg VM, Haqqi TM. Phenyl $\mathrm{N}$-tert-butylnitrone down-regulates interleukin-1 $\beta$-stimulated matrix metalloproteinase-13 gene expression in human chondrocytes: suppression of c-Jun NH2-terminal kinase, p38-mitogen-activated protein kinase and activating protein-1. J Pharmacol Exper Ther 2003; 305: 981-8.

90. Baker SJ, Kerppola TK, Luk D, Vandenberg MT, Marshak JR, Curran $\mathrm{T}$ et al. Jun is phosphorylated by several protein kinases at the same sites that are modified in serum-stimulated fibroblasts. Mol Cell Biol 1992; 12: 4694-705.

91. Hibi M, Lin A, Smeal T, Minden A, Karin M. Identification of an oncoprotein- and UV-responsive protein kinase that binds and potentiates the c-Jun activation domain. Genes Dev 1993; 7: 2135-48.

92. Karin M. The regulation of AP1 activity by mitogen-activated protein kinase. J Biol Chem 1995; 270: 16483-6.

93. Han Z, Boyle DL, Chang L, Bennett B, Karin M, Yang L, et al. c-Jun $\mathrm{N}$-terminal kinase is required for metalloproteinase expression and joint destruction in inflammatory arthritis. J Clin Invest 2001; 108 : 73-81.

94. Davis RJ. Signal transduction by the c-Jun terminal kinase. Biochem Soc Symp 1999; 64: 1-12.

95. D'Arcangelo G, Tancredi V, Onofri F, D'Antuono M, Gioverdi S, Benfenati F. Interleukin-6 inhibits neurotransmitter release and the spread of excitation in the rat cerebral cortex. Eur J Neurosci 2000; 12: $1241-52$

96. Tancredi V, D'Antuono M, Cafe C, Giovedi S, Bue MC, D'Archange- lo $\mathrm{G}$, et al. The inhibitory effects of interleukin-6 on synaptic plasticity in the rat hippocampus are associated with an inhibition of mitogen-activated protein kinase ERK. J Neurochem 2000; 75: 634-43.

97. Shioda S, Ozawa H, Dohi K, Mizushima H, Matsumoto K, Nakajo S, et al. PACAP protects hippocampal neurons against apoptosis: involvement of JNK/SAPK signaling pathway. Ann NY Acd Sci 1998; 865: 111-7.

98. Xu FH, Sharma S, Gardner A, Tu Y, Raitano A, Sawyers C, et al. Interleukin-6-induced inhibition of multiple myeloma cell apoptosis: support for the hypotesis that protection is mediated via inhibition of the JNK/SAPK pathway. Blood 1998; 92: 241-51.

99. Adler V, Franklin CC, Kraft AS. Phorbol esters stimulate the phosphorylation of c-Jun but not v-Jun: regulation by the N-terminal delta domain. Proc Natl Acad USA 1992; 89: 5341-5.

100. Ye J, Zeidler P, Young SH, Martínez A, Robinson VA, Jones W, et al. Activation of mitogen-activated protein kinase p38 and extracellular signal-regulated kinase is involved in glass fiber-induced tumor necrosis factor-alpha production in macrophages. J Biol Chem 2001; 276: 5360-7.

101. De la Torre P, Díaz-Sanjuán T, García-Ruiz I, Esteban E, Canga F, Muñoz-Yagüe T, et al. Interleukin-6 increases rat metalloproteinase13 gene expression through Janus kinase-2-mediated inhibition of serine/threonine phosphatase-2A. Cellular Signalling 2005; 17: 42735 .

102. Wera S, Hemmings BA. Serine/threonine protein phosphatases. Biochem J 1995; 311: 17-29.

103. Westermarck J, Lohi J, Keski-Oja J, Kaharri VM. Okadaic acidelicited transcriptional activation of collagenase gene expression in HT-1080 fibrosarcoma cells is mediated by JunB. Cell Growth Differ 1994; 5: 1205-13.

104. Kim SJ, Lafyatis R, Kim KY, Angel P, Fujiki H, Karim M, et al. Regulation of collagenase gene expression by okadaic acid, an inhibitor of protein phosphatases. Cell Regul 1990; 1: 269-78.

105. Thévenin C, Kim S-J, Kehrl JH. Inhibition of protein phosphatases by okadaic acid induces AP1 in human T cells. J Biol Chem 1991; 266: 9363-6.

106. Al-Murrani SW, Woodgett JR, Damuni Z. Expression of I2PP2A, an inhibitor of protein phosphatases 2A, induces c-Jun and AP-1 activity. Biochem J 1999; 341: 293-8.

107. Mumby MC, Walter G. Protein serine/threonine phosphatases: structure, regulation, and functions in cell growth. Physiol Rev 1993; 73: 673-99.

108. Cohen P, Holmes CFB, Tsukitani Y. Okadaic acid: a new probe for the study of cellular regulation. Trends Biochem Sci 1990; 15: 98102.

109. Peng J, Bowden GT, Domann FE. Activation of AP-1 by okadaic acid in mouse keratinocytes associated with hyperphosphorylation of c-jun. Mol Carcinog 1997; 18: 37-43.

110. Grumbles RM, Shao L, Jeffrey JJ, Howell DS. Regulation of rat interstitial collagenase gene expression in growth cartilage and chondrocytes by vitamin D3, interleukin-1 beta, and okadaic acid. J Cell Biochem 1996; 63: 395-409.

111. Csortos C, Zolnierowicz S, Bako E, Durbin SD, DePaoli-Roach AA. High complexity in the expression of the B subunit of protein phosphatases 2A. Evidence for the existence of at least seven novel isoforms. J Biol Chem 1996; 271: 2578-88

112. Zolnierowicz S. Type $2 \mathrm{~A}$ protein phosphatase, the complex regulator of numerous signaling pathways. Bichem Pharmacol 2000; 60: 122535 .

113. Chen J, Martin BL, Brautigan DL. Regulation of protein serine-threonine phosphatases type-2A by tyrosine phosphorylation. Science 1992; 257: 1261-4.

114. Chen J, Parsons S, Brautigan DL. Tyrosine phosphorylation of protein phosphatases $2 \mathrm{~A}$ in response to growth stimulation and $\mathrm{V}$-src transformation of fibroblasts. J Biol Chem 1994; 269: 7957-62.

115. Begum N, Ragolia L. Role of janus kinase-2 in insulin-mediated phosphorylation and inactivation of protein phosphatase-2A and its impact on upstream insulin signalling components. Biochem J 1999; 344: 895-901.

116. Srinivasan M, Begum N. Stimulation of protein phosphatase -1 acttivity by phorbol esters. Evaluation of the regulatory role of protein kinase C in insulin action. J Biol Chem 1994; 269: 16662-7. 
117. Liu KD, Gaffen SL, Goldsmith MA. JAK/STAT signaling by cytokine receptors. Curr Immunol 1998; 10: 271-8

118. Woetmann A, Nielsen M, Christiansen ST, Brockdorff J, Kaltoft K, Engel AM, et al. Inhibition of protein phosphatase $2 \mathrm{~A}$ induces serine/threonine phosphorylation, subcellular redistribution, and functional inhibition of STAT3. Proc Natl Acad Sci USA 1999; 96: 10620-5.

119. Choi I, Lee MJ, Kim EJ, Kang HS, Pyun KH. Roles of protein phosphatase 2A in IL-6 signal transduction in Hep3B cells. Immunol Lett 1998; 61: 103-7.

120. Gómez-Lechón MJ. Oncostatin M: signal transduction and biological activity. Life Sci 1999; 65: 2019-30.

121. Taga T, Kishimoto T. Gp130 and the interleukin6 family of cytokines. Annu Rev Immunol 1997; 15: 797-819.

122. Miyajima A, Kinoshita T, Tanaka T, Kamiya A, Mukuoyama Y, Hara T. Role of Oncostatin M in hematopoiesis and liver develop-ment. Cytokine Growth Factor Rev 200; 11: 177-83.
123. Saad MJ, Carlvaho CR, Thirone AC, Velloso LA Insulin induces tyrosine phosphorylation of JAK2 in insulin-sensitive tissues of the intact rat. J Biol Chem 1996; 271: 22100-4.

124. Glenn G, Eckhart W. Amino-terminal regions of polyomavirus middle $\mathrm{T}$ antigen are required for interactions with protein phosphatase $2 \mathrm{~A}$. J Virol 1995; 69: 3792-36.

125. Yokoyama N, Reich NC, Miller WT. Determinants for the interaction between Janus kinase 2 and protein phosphatase 2A. Arch Biochem Biophys 2003; 417: 87-95.

126. Yokoyama N, Reich NC, Miller WT. Involvement of protein phosphatase $2 \mathrm{~A}$ in the interleukin-3stimulated Jak2-Stat5 signaling path-way. J Interferon Cytokine Res 2001; 21: 369-78.

127. Fuhrer DK, Yang YC. Complex formation of JAK2 with PP2A, P13K, and Yes in response to the hematopoietic cytokine interleukin-11. Biochem Biophys Res Commum 1996; 224: 289-96.

128. Meydan N, Grunberger T, Dadi H, Shahar M, Arpaia E, Lapidot Z, et al. Inhibition of acute lymphoblastic leukaemia by a Jak-2 inhibitor. Nature 1996; 379: 645-8. 